\title{
PUBLIC PARTICIPATION IN PROTECTING FOOD RESOURCES: THE CASE OF FEDERAL LANDS IN PICKERING
}

by

\author{
Sanja Kornicer \\ Bachelor of General Studies, Indiana University, 2010
}

A master's project paper presented to Ryerson University in partial fulfillment of the requirements for the degree of

\author{
Master of Applied Science \\ in the program of \\ Environmental Applied Science and Management
}

Toronto, Ontario, Canada, 2020

(C) Sanja Kornicer 2020 


\section{AUTHOR'S DECLARATION}

I hereby declare that I am the sole author of this project paper. This is a true copy of the project paper including any required final revisions.

I authorize Ryerson University to lend this project paper to other institutions or individuals for the purpose of scholarly research. I further authorize Ryerson University to reproduce this project paper by photocopying or by other means, in total or in part, at the request of other institutions or individuals for the purpose of scholarly research.

I understand that my project paper may be made electronically available to the public. 


\section{Acknowledgments}

I wish to express my deepest gratitude to my supervisor Dr. Mustafa Koc for guiding and encouraging me to be professional and do the right thing when the road got tough. Without him, I would not be where I am today. I want to thank Dr. Cheryl Teelucksingh for her advice and guidance in my writing. I am especially indebted to Dr. Cory Searcy and Dr. Andrew Laursen, the directors of the program who recognized my struggles and supported me during my studies. And I wish to express special gratitude to Elias Chu and Stephanie Assenza for guiding me through the administration when I thought graduating was an impossible task.

I would also like to express my gratitude to Mary Delaney and Gabrielle Untermann for sharing their knowledge and archives with me. I wish I had collaborated more with them on this project.

Finally, my special love and gratitude go to my family, to my daughters Jovana and Jelena and my husband Mihajlo, who kept me moving forward. 
Public Participation in Protecting Food Resources: The Case of Federal Lands in Pickering Master of Applied Science, 2020

Sanja Kornicer

Environmental Applied Science and Management

Ryerson University

\begin{abstract}
In 1972, the federal government's plan to build the second major Toronto airport in the north Pickering area met strong public resistance that put the project on hold in 1975. This project investigates the role of public engagement in land use policy and the protection of agricultural lands by reviewing the literature on the Pickering Airport from a historical perspective and conducting archival research of historical records and documents from 1972 to the present. Consulting the literature on public discourse, I examine whether a 45 year-long delay in the completion of the airport could be solely attributed to public participation in policy making. The paper will focus on effective use of media, scientific evidence and expert advice that are leading to deadlocks in a process full of inconsistencies in government decision making, influenced by electoral politics, changing governments and jurisdictional differences between federal and provincial governments.
\end{abstract}




\section{Table of Contents}

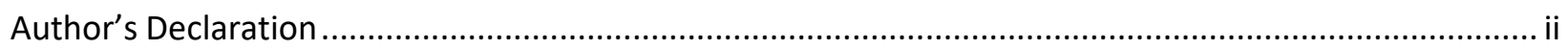

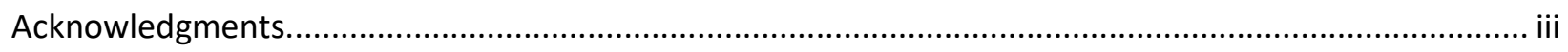

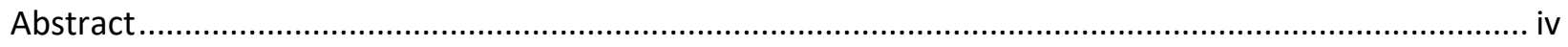

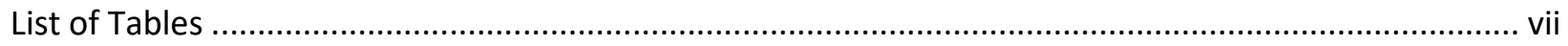

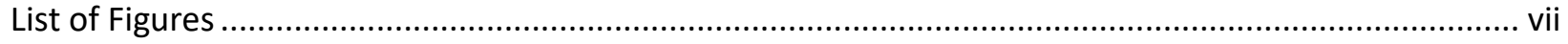

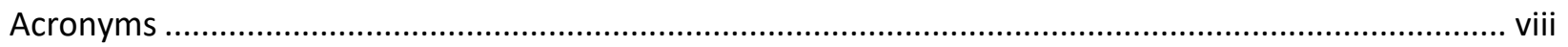

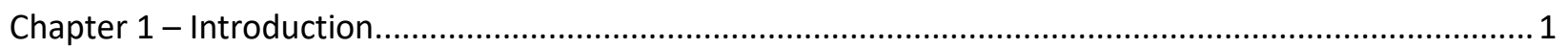

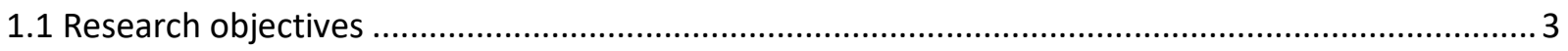

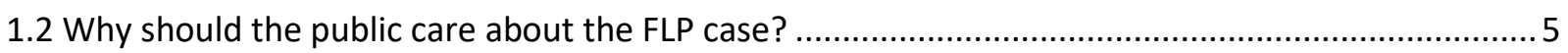

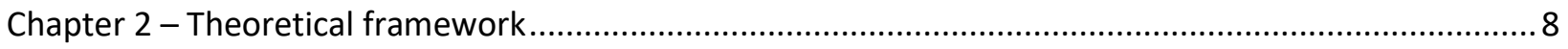

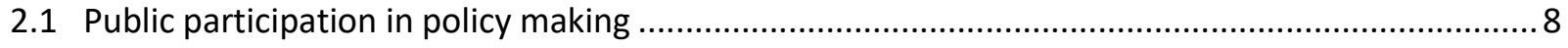

2.1.1 Advantages and disadvantages of public participation .................................................... 9

2.1.2 'Bad' vs. 'good' resistance to public projects ......................................................................... 11

2.2 Use of scientific discourse by citizens in the policy making process........................................... 12

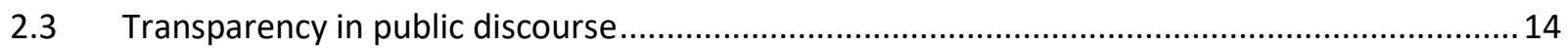

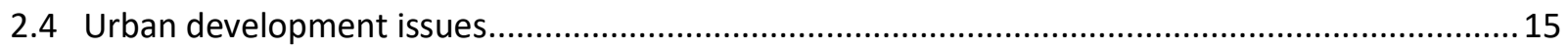

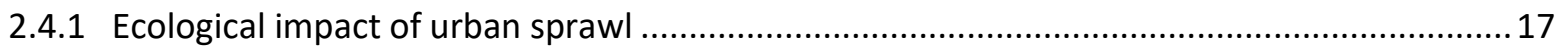

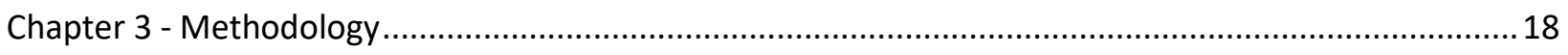

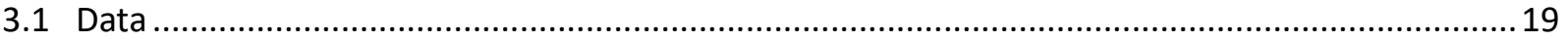

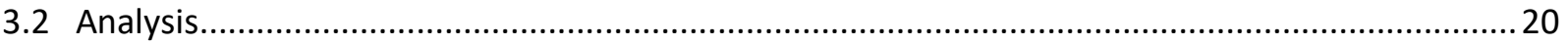

Chapter 4 - Protecting food resources: battles for Pickering lands .................................................... 22

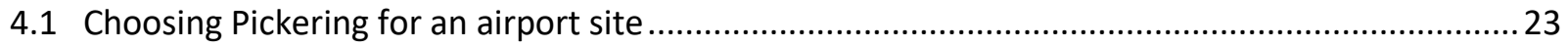

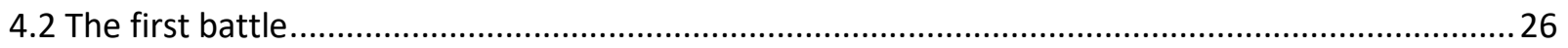

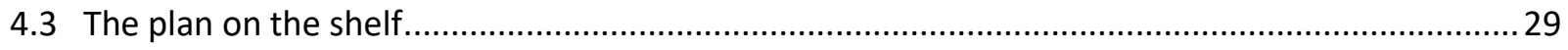

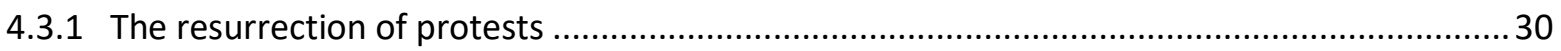

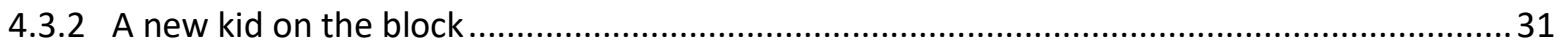

4.3.3 Why the 'calm' period lasted so long ............................................................................ 32

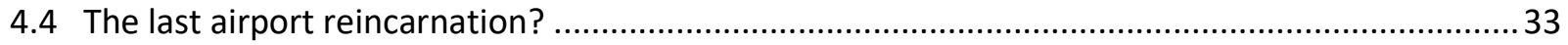

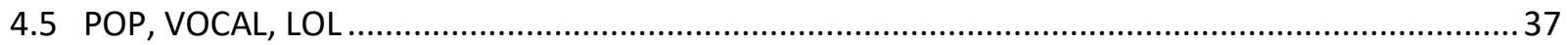

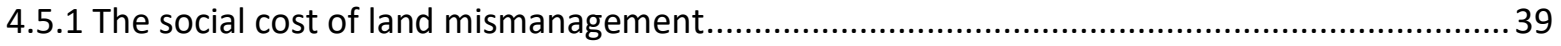

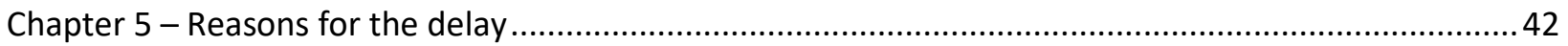




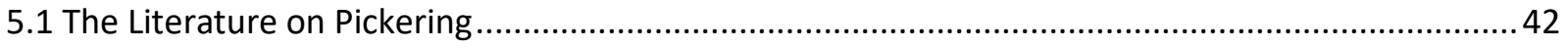

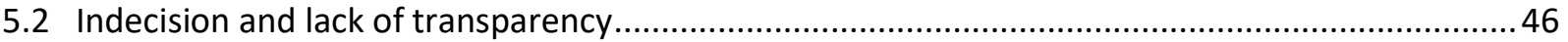

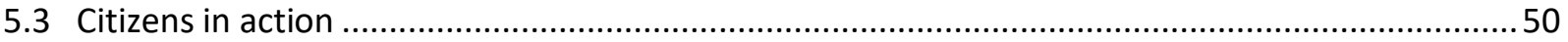

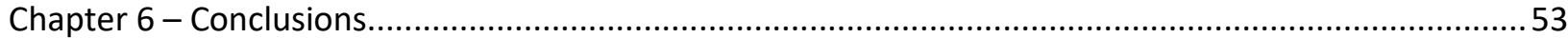

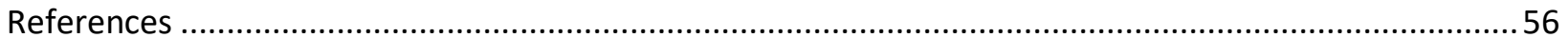




\section{List of Tables}

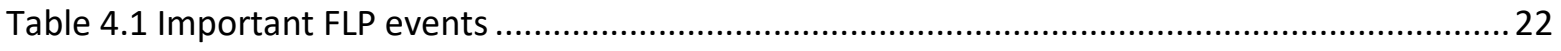

Table 5.2 Studies performed to determine when the Pickering Airport would be needed............... 47

\section{List of Figures}

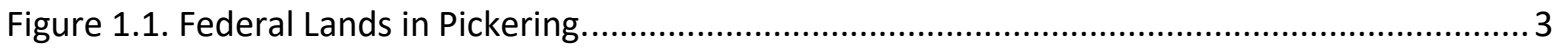

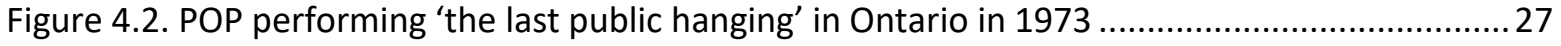

Figure 4.4. Remaining FLP lands and two parcels that now connect the RNUP with the ORM........34 


\section{Acronyms}

AIC Airport Inquiry Commission.

FLP Federal Lands in Pickering.

GA General Aviation.

GDA Green Durham Alliance.

GTA Greater Toronto Area.

GTAA Greater Toronto Airport Authority.

LOL Land over Landings.

MP Member of Parliament.

ORM Oak Ridges Moraine.

PC Parks Canada.

POP People or Planes.

RNUP Rouge National Urban Park.

SOAAS South Ontario Area Airports Study.

SOMTS South Ontario Multimodal Transportation Study.

TC Transport Canada.

V.O.C.A.L. Voters Organized to Cancel the Airport Lands. 


\section{Chapter 1 - Introduction}

In 1972, the federal government expropriated 18,600 acres (7530 ha) of prime agricultural lands in the area of north Pickering, Markham, Uxbridge and Stouffville. The land was designated for the second major airport in the Greater Toronto Area (GTA) to supplement Toronto Pearson International Airport, formerly known as Malton Airport (Winsor, 1972). In the vicinity of the future airport, an additional 25,000 acres were expropriated by the Ontario government for the development of a future city named Cedarwood to support the airport, and the overall eastward development of the Toronto region (Ontario Government, 1972). While the development of the envisioned community of 150,000 to 200,000 residents was delayed for a long time for various reasons, a new community of $\sim 70,000$ residents named Seaton in north Pickering is currently on its way (McNair, 2019). However, the airport has not been built because of strong public resistance. The project was stopped and the fate of the remaining Federal Lands in Pickering (FLP) is still uncertain.

The land in question is located north-east of the GTA, immediately south to Oak Ridges Moraine (ORM), which is a major ground water recharge zone, now protected from uncontrolled urban development by the Oak Ridges Moraine Conservation Act (2001). Figure 1.1 shows the FLP area, with the brown region showing land that is within ORM. Important heritage structures on these lands were identified after expropriations that started following the 1972 announcement. Before the expropriations, the area was known as the birth place of pedigree-livestock breeding in Canada, initiated by the Miller family in the 19th century (Historic Sites and Monuments Board of Canada (HSMBC), 1973). The most important characteristic of the FLP is that it is Class 1 farmland, which is a highly valued place for farming in such a close proximity to the large urban area of the GTA. Public opposition to the airport plan began in 1972, spearheaded by a community-based environmental organization (CBEO) known as People or Planes (POP), aiming to protect the FLP for farming.

One important characteristic of the FLP project is the coupling between the federal and provincial governments. Based on the initial agreement, the federal government would be 
responsible for building the airport while the province would provide supporting infrastructure. That fact had a profound consequence at the early stage in the process.

In the first three years conflicting political, economic, and technical pressures created difficulties that prevented the project from taking off (Ball, 1991), and the federal government shelved the plan in 1975. The plan was dormant for almost 20 years, then revised, and in 2013 the government announced that there was a surplus of land not needed for the airport, while maintaining that the airport in Pickering would be needed some time in the future, possibly between 2035 and 2045. Consequently, in the period from 2015 to 2017 a half of originally expropriated land changed its designation, and around 10,000 acres were transferred from Transport Canada (TC) to Parks Canada (PC). The surplus land became a part of the Rouge National Urban Park (RNUP). Although at a smaller scale than initially envisioned, the federal government is still keeping the option to build an airport in the future.

The main argument of the protesters is that estimated projections exaggerated passenger traffic to justify the new airport, and that a real need for the airport has not been established, particularly not the need to convert prime agricultural land into the concrete for the airport strips. Over time, stakeholders on both sides of the Pickering Airport issue conducted studies or made recommendations that were contested and often ignored. Warner (1981) pointed out that the government research for the need for, and the place of the second largest GTA airport had been extensive at the beginning of the process, but it was not balanced because 'the case for simply expanding the existing international airport at Toronto might have been understated'. In 1984, the Malton Airport was renamed as Pearson in honour of former Prime Minister Lester B. Pearson. While the decision to expand the Pearson Airport was eventually made some 20 years later, almost every 10 years the federal government brings forth the idea of building the airport in Pickering, and conducts studies to justify this idea. Citizens concerned for the farmland, including environmentalists, farmers, and the local community, were fighting back with their own studies, and the federal government has been promising more studies. The perpetuity of this cycle protracted the project for 50 years, and the gap between citizens, government and policy planners still remains. We know that science and expertise are integrated into the decisionmaking process, but that did not reduce the bitterness of public discourse, which has been persistent for a long period of time. 
The civic opposition to the project is still continuing. It is now led by the POP successor, Land over Landings (LOL). The group is still arguing that there is no justification for a new airport in Pickering (Delaney, 2018). The last study regarding the viability and necessity of the Pickering Airport was ordered by the federal government in 2016. Two-thirds of this study was done in the first half of 2019, but the findings have not been released. At the beginning of 2020, all stakeholders in this story are awaiting the final report.

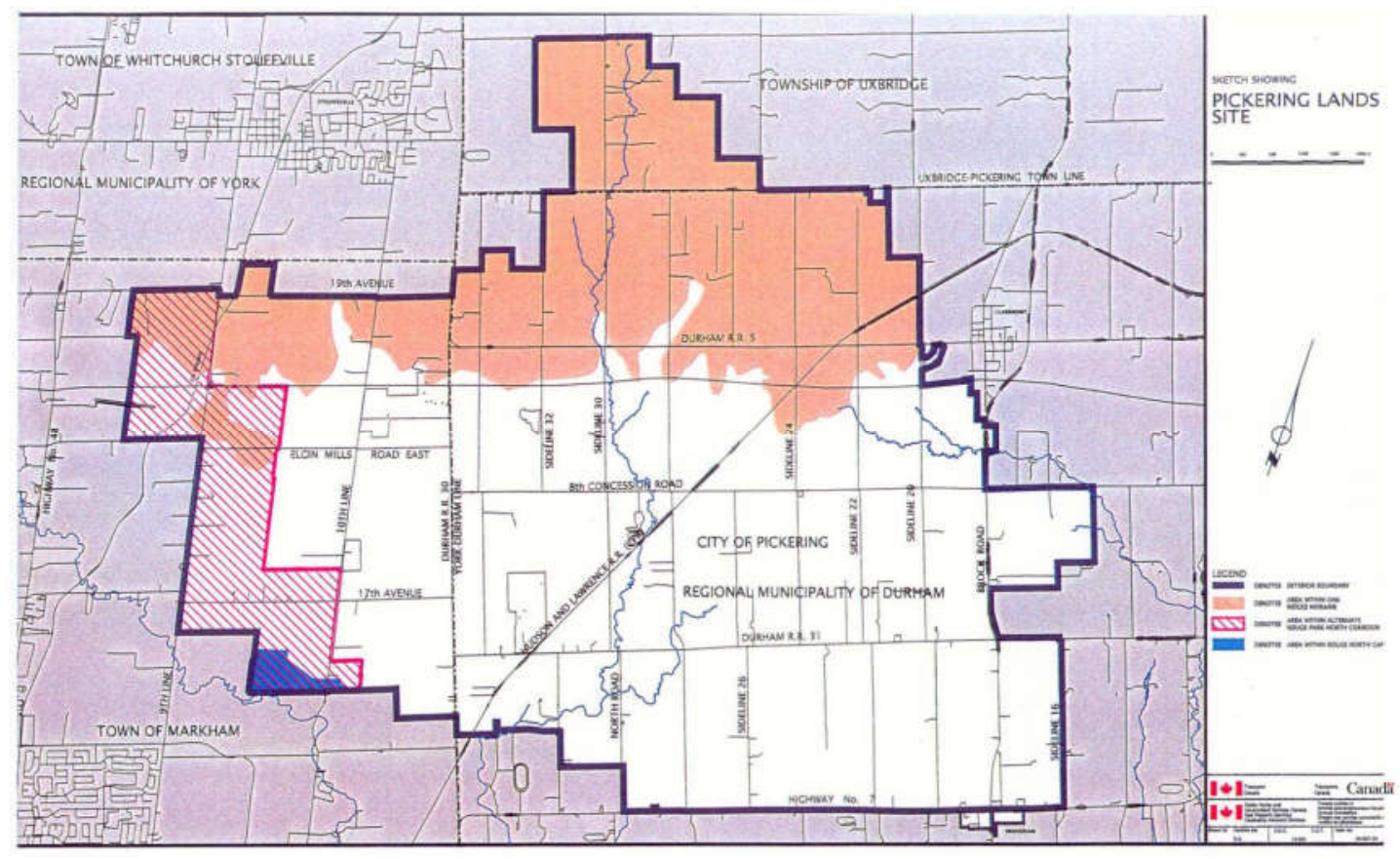

Figure 1.1. Federal Lands in Pickering.

\subsection{Research objectives}

The role of a grass-root movement to oppose the airport development is worth investigating since after so many years the project is still in limbo. This is the only airport project in Canada that has been put on hold for so long (McGrath, 1992; Rowan, 2017). This story has been examined and discussed in literature that focused mainly on the early period of conflicts, from 1972 to 1975 . The main conclusions from the scholarly research are briefly summarized here. Thompson (1994), who participated in the protests, showed that a relatively small group of citizens can stop the government's mega-plans if they learn how to successfully utilize science and expertise to confront government experts. In addition, they need to be smart and witty in 
order to have the media on their side to sway the general public, which is also emphasized by Rowan (2019), who analyzed citizen and government interactions regarding three airport projects in Canada in the 1970s, including Pickering. In his paper devoted to the Pickering Airport, Rowan (2017) questions the effectiveness of public participation in determining land-use policy.

The Public had been excluded from the decision-making process during the early stage of this case, but over time public participation has become an important element of land use planning. Public participation in land use planning is essential for the transparency of the process, in which informed public can counter the influence of private interests that are privileged within the political economy of given jurisdiction(s) or the ideological commitments of a ruling party (Adkin et. al, 2017). Public engagement brings insights from multi-stakeholders that can help avoid costly mistakes in the future, but this process also has its shortcomings. The goal of this research is to answer the question: are public consultations effective in the policy making that government(s) should adhere to? If not, what other methods of public participation in the discourse could be employed to help marginalized voices to be heard?

In this paper I will investigate the role of public engagement in land use policy and the protection of agricultural lands by reviewing the literature on Pickering Airport from a historical perspective and examining if the delay in completion of the airport could be attributed to public participation in the policy process. I will provide a review of literature of previous studies on this case, complemented with archival research of historical records and documents from 1972 to the present. Looking at the power dynamics among those who have been involved in this process requires insights from the literature on environmental politics to examine whether citizens could negotiate with more powerful economic interests such as developers and different levels of government that may have more resources and access to information. Specifically, I will examine the role of effective use of media, expert advice and the political processes by the opponents as delaying strategies. I will also explore the inconsistencies in the government decision making process as influenced by electoral politics, changing governments and jurisdictional differences among federal, provincial and municipal governments.

The answer to the question of whether public consultations and forums are needed and useful in bringing a sustainable outcome for Pickering lands should be valuable to government planners responsible for viable and timely development, academic researchers interested in the role of public input in development projects, and civil society organizations interested in 
environmental protection. For planners, this ENSCIMAN research may provide insights on how to use public consultations in an effective way to gain public feedback in order to avoid lengthy delays in development projects. Providing more information on how citizens can help in preserving agricultural lands is also important, because Class 1 soil covers only $0.5 \%$ of all Canada land (Pierce and Ward, 2013). Only seven percent of Canada's overall landmass is suitable for farming; of this amount, Ontario holds around eight percent (Veeman and Veeman, 2018). At the same time, Ontario and Quebec are holding more than 55\% of Canada's urbanized land, and this proportion is constantly growing because of urban and industrial sprawl (Hofmann, 2001).

\subsection{Why should the public care about the FLP case?}

Understanding the FLP case is important for several environmental, economic and political reasons. There are broad issues that should concern all citizens, such as climate change and sustainable economy, land preservation and food security. Canadian society needs clear answers in order to deal with the contradictory pressures regarding demand for urban development and economic progress and concerns around urban sprawl and the need for environmental protection. The food security and land-use policies are both relevant in the context of climate change. The federal government has the obligation to reduce Canada's carbon footprint because it signed the UN Paris Agreement (UN Framework Convention on Climate Change, 2015). At the same time, Ontario is one of the provinces resisting the federal policy for reducing $\mathrm{CO}_{2}$ emissions (McGregor, 2018). Climate change threatens to disrupt food production all over the world (Intergovernmental Panel on Climate Change (IPCC), 2018), so keeping agricultural lands may be considered as an important tool in the fight against climate change.

The soil quality in the FLP area is classified as Class 1, on the scale of 1-7, where Class 1 has no significant limitations in use for crops, and Class 7 refers to land with no arable capacity (Pierce and Ward, 2013). Toronto is constantly growing, and growing food close to consumers by utilizing the fertile lands in Pickering is important for food security and the local economy. One of the goals of the Toronto City Council that was set through the Toronto Food Charter, adapted by the Toronto Food Policy Council (2001), is to ensure a viable and sustainable food production system. Providing sustainable food security for large cities like Toronto could be challenging in the future, because growing food through mechanized agriculture, and 
transporting vegetables, fruit, and meat over long distances into cities by trucks, ships, and planes, could become increasingly costly and difficult (Lang, 2018). According to Lang, currently there is no realistic possibility for any major city to replace fossil fuels with renewable energy in the food-supply chain. Reducing reliance on global food production would help avoid transportation problems, which create more carbon emissions. Besides, growing food in the city provides many economic, health, environmental and community benefits (Toronto Urban Growers, 2019), and helps fulfil the goals of the Toronto Food Charter.

The second important economic issue is that society should avoid costly projects and massive misplaced investments, like the Mirabel Airport. Mirabel was envisioned to replace Dorval Airport near Montreal, around the time when the Pickering project was concocted. However, it turned out to be one of the largest failed investments of the Canadian government: Mirabel opened in 1975 and closed for passengers in 2004 (Krauss, 2004), because millions of projected passengers did not show up. Delaying large government projects also costs taxpayers, but probably less than building unnecessary infrastructure.

The cost of the FLP saga so far is not known: one attempt made by Stewart (1979) put a half billion dollar price tag for the early stage of the development, which included 120 million dollars for expropriations (Transport Canada, 2011). The cost of land management and all the government studies will probably never be known. The compound loss of revenue and food production from ill-used lands is also significant, because for decades only one-year agricultural leases were issued by Transport Canada (2017). Short-term leases do not encourage long-term investments in more profitable agricultural production, so long-term tenancy security becomes a crucial factor for farm viability. Airport proponents were using this issue, claiming that the land is not that valuable since it appeared fallow for outside observers. However, Kubursi and Groenewegen (2018) estimated that the economic activity dropped significantly between 1972 and 2016. There is also a social cost associated with mega projects that are built without careful planning, in this case in particular. Although the project is delayed, demolitions of properties started early, and continued since then.

One possible benefit of preserving this land for the public, as pointed out by POP and LOL ('Airport plan shelved', 1985; Land over Landings, 2018), is that this land can be used as a training hub for modern agriculture, to educate and help young aspiring farmers establish themselves. The population of farmers in Canada ages, as well as the general population, but the 
relative population of farmers declined substantially in recent decades. In 1971, one in 14 Canadians was a member of the farming population, while in 2016 that number had decreased to one in 58 Canadians (Statistics Canada, 2018).

Finally, there is also the political aspect of investing in airport development, which should be undertaken if the need is truly demonstrated, and alternative solutions of exploring existing airport network of Southern Ontario are not viable. Twenty years after shelving the original Pickering Airport plan, Neufville (1995) warned that if the future airport site in a multiairport environment is not an actual airport but looks like a nature preserve, such as the FLP, it could be politically impossible to be transformed into an airport. It is difficult to justify a new airport on undeveloped land when there are other airports such as Pearson, Hamilton and Toronto Island in close proximity. 


\section{Chapter 2 - Theoretical framework}

This story revolves around public participation in land-use policy and the transparency of the decision-making process, how knowledge is distributed and how it is used to educate and persuade the parties involved, and how the politics of environmental management affected a development project, which would have a significant environmental impact.

\subsection{Public participation in policy making}

Public participation has become a central element of land use planning over the last decades (Laurian and Shaw, 2008; Fung, 2015), and stakeholder participation is increasingly being sought and embedded into environmental decision-making processes, from local to international scales (Reed, 2008). Broadly, public participation can be defined as the process by which public concerns, needs, and values are incorporated into governmental decision making, with the goal of achieving decisions that are supported by the public (Creigton, 2005). The participatory processes can be classified by who participates, and how information between participants is exchanged. Fung (2006) distinguishes participation between processes open to all who wish to engage and the invitation-only type. Regarding information flow, Pickering and Minnery (2012) consider that two-way communications and interactions define public participations. Fung (2006) is more inclusive: the participation processes could be deliberative but the information can flow one way as well. Examples of processes open to all are public consultation periods during which anyone can comment on a specific policy that government is considering, but are usually one-way communications since there is seldom immediate feedback from government representatives. The invitation-only type would be a parliamentary session in which representatives from interested stakeholders are invited to discuss an issue with policy makers. This is also an example of deliberative participation, which represents a smaller set of public meetings, because the common practice of government representatives is to announce and explain policies without taking input from citizens (Fung, 2006).

As public participation is increasing the way the public is engaged is shifting from being a passive observer of decisions delivered by government officials and experts, to demanding a 
more comprehensive, participatory and transparent environmental decision-making process (Savan et al., 2004; Jami and Walsh, 2014). It is not only that the public is asking for changes, but also the government is seeking greater public input to reduce democratic discontent and to enhance citizens' sense of their political efficacy (Culver and Howe, 2004; Irvin and Stansbury, 2004). One example of environmentally aware citizens engaging government agencies is the building of a regional coalition of environmentalists, residents and the provincial government to protect the ecologically sensitive and agricultural lands of the ORM (Gilbert et al., 2009). In contrast, Rowan (2019) claims that public participation in airports planning in Canada during 1970s did not bring expected benefits. Rowan investigated the cases of Pickering in Ontario, Mirabel in Quebec, and Sea-Island in British Columbia. In all three of the airport developments, the federal government did consult with citizens and shifted its strategies of dealing with citizens, but the citizens' groups were not satisfied by the outcomes ${ }^{1}$.

\subsubsection{Advantages and disadvantages of public participation}

In the debate whether community participation is an effective policy-making tool, Irvin and Stansbury (2004) claim that public participation in government decisions brings important benefits for the outcomes, if the citizens' mandate is needed to resolve a gridlock, or improve policy implementation. Deliberations are found to be effective in unlocking the process when decision making is brought to a halt (Weeks, 2000). Irvin and Stansbury (2004) identify the educational component in the decision-making side of participation processes to be beneficial to all parties involved because public and government can learn from each other. The need for the public to learn about issues regarding specific policy is self-evident, but governments could benefit from finding out about citizens' concerns and contentious issues before policy is made. In that regard, the open and equal access to public deliberations is important. The diversity of ideas and the inclusion of a large variety of standpoints, backgrounds and experiences enhance the learning effects of deliberative processes (Krick, 2019). One drawback of open access is the 'self-selection' of participants. Those who are wealthier, more educated or have stronger views are more likely to engage in unconventional deliberations, which can skew the discussions and

\footnotetext{
${ }^{1}$ The Pickering project was delayed but the land is retained for the airport, never to be returned to residents. Mirabel was built and the land owners could not have known that more than 90,000 acres of expropriated land would be returned by 2006. Finally, the expansion of Sea-Island Airport was delayed for 15 years, and eventually in 1991, the additional runway got the green light.
} 
outcomes towards those who are more interested or have special financial interests (Irvin and Stansbury, 2004; Fung, 2006)

The spatial distribution of participants also matters. When the stakeholders are in close proximity and more homogeneous, requiring a smaller number of representatives, it can positively impact decision-making process (Irvin and Stansbury, 2004). The disadvantage of citizens who live at larger distances from the places of deliberations, and who are not incorporated, arises when they need to finance their participation. Public interest groups very often do not have the resources to accept invitations to policy advisory committees (Krick, 2019). Thus, a shortcoming of open invitations to engage the public in large-scale consultations manifests when only a limited number of participants respond, which undermines the value of public input (Culver and Howe, 2004).

Whether public participation improves outcomes in sustainability planning is questioned by Kinzer (2018) as well, showing that public participation can have a negative impact on the implementation speed when higher numbers of participants in the planning process cause slower policy implementation. Larger participation is not better in that regard, but structuring public participatory processes to enhance the speed of policy implementation by restricting participation is not ethically acceptable (Kinzer, 2018), particularly if marginalized voices are not heard. Generally, slowing down large public projects is considered costly and ineffective (Irvin and Stansbury, 2004; Teo and Loosemore, 2017), and puts pressure on managers of large public projects. However, participation should be considered as early as possible by engaging and representing relevant stakeholders systematically (Reed, 2008). Understandably, protests could be expected if the social and environmental impacts of a project are not properly addressed, or when people feel that their future is at stake (Hanna et al., 2016). This is closely related to the concept of Free, Prior and Informed Consent (FPIC) (Hanna and Vanclay, 2013), developed to protect the rights of Indigenous people in large projects. However, the need to follow this concept can be applied more broadly, since it is evident that the federal government in Canada did not observe its main pillars: prior, informed, consent; when making decisions regarding developing the Mirabel and Pickering Airports decades ago. When protests erupt, this is a telling indicator of problems that were neither registered nor dealt with in an adequate manner (Rucht et al., 1999). The question remains how much the government should pay attention to the concerns of citizens in planning for large public projects. 
According to Reed (2008), 'future research needs to evaluate whether decisions emerging from participatory processes are perceived to be more holistic and representative of diverse values and needs, and whether this has the capacity to enhance public trust in the decisionmaking process.' The large infrastructure projects, like airports, may require extensive planning and the public may not have all the information to make a healthy decision (Rowan, 2017). Rowan argues that there are profound consequences when citizens reject experts' opinion and make it more difficult to implement large-scale public works projects. In these cases, the remedy may come from the educational aspect of engaging the public in the policy-making process. Informed and involved citizens become citizen-experts, able to understand technically difficult situations and see holistic, community-wide solutions (Irvin and Stansbury, 2004). One issue in the participatory processes that is hard to overcome is when there are 'veto players', entities whose agreement is required for a policy decision (Tsebelis, 1995), which can be detrimental to achieving environmentally sound or good publicly oriented decisions (Newig et al., 2018).

\subsection{2 'Bad' vs. 'good' resistance to public projects}

Public protests and resistance to large projects are often seen as actions motivated by selfinterest, known as NIMBYism (Not-In-My-BackYard). Dear (1992) defines NIMBYism as 'the oppositional tactic adopted by community groups facing an unwelcome development in their neighborhood'. NIMBY cases tend to happen frequently when potential property losses are involved, and they are occurring all over the world (Tang et al., 2005; Vanclay et al., 2015; Lee et al., 2017; Teo and Loosemore, 2017). The phenomenon usually holds a derogatory connotation, based on the perception that a smaller subset of the public is resisting a project that has the potential to generate larger public good (Palma-Oliveira et al., 2018), like wind farms or airport developments (Jami and Walsh, 2014; Vanclay et al., 2015). However, this labeling is not always helpful in developing effective project management strategies to engage with communities which often have genuine and justifiable development concerns (Teo and Loosemore, 2017). This is particularly true if the local movement brings in region-wide policies that protect fresh air, water, soil and biodiversity (Gilbert et al., 2009; Abbruzzese and Wekerle, 2011). Justified or not, citizens resisting construction projects incur social costs related to compliance, enforcement and conflict (Armitage et. al, 2012), which can be substantial. Lee et al. 
(2017) put a price tag of US $\$ 70$ billion annually on alleviating and managing social conflicts associated with large public projects in South Korea.

On the other hand, one can argue that slowing projects when all important social or environmental aspects are not addressed properly might be beneficial. For example, if the public had more time to assess all the issues with the Mirabel project, and protest with the intensity of the Pickering protests, that might have been considered one successful story in preventing wasteful government spending (Elliot, 2014). Rowan (2019) states that citizen's side of the Mirabel story has not been addressed thoroughly by scholars, perhaps because their resistance failed. In any case, if big government projects are unchecked they can lead to large losses for society. Unless care is taken in the selection of social investment expenditures, a project can become a 'white elephant', which is a term that refers to a high-cost project or facility with limited usefulness (Vanclay et al., 2015). It is hard to settle the debate about public participation in land-use policies without experts' opinions, who are usually employed on both sides of the public policy arguments.

\subsection{Use of scientific discourse by citizens in the policy making process}

The science and scientific expertise play important roles for public participation in government decisions. This has been long recognized by scholars, as well as protesters. Thompson (1994), who participated in the POP protests that helped stop the airport development on rural lands in Pickering, explained how a relatively small group of people can fight the government utilizing its own experts and scientist. The role of science employed by citizens in land-use policy in Ontario was examined by Macaraig (2015), showing that this is a powerful tool that citizens can use in protecting green space, such as the Rouge River watersheds that are now protected within the RNUP. Macaraig (2015) identifies three distinct ways civil society groups utilized scientific expertise to facilitate and enforce a conservation narrative. First, they identified and utilized existing scientific reports. Second, they published their own reports/studies. Third, they applied a hands-on approach and initiated community-based restoration and monitoring programs. These include projects such as ecological monitoring, tree, shrub and wildflower plantings, habitat restoration, and even environmental education.

In general, CBEOs can participate in scientific research projects that can examine economic, social and environmental aspects of proposed developments, which are important as 
strategies to increase local participation and stewardship (Whitelaw et al., 2003; Vanclay et al., 2015; Macaraig, 2015). Science and expert opinions are needed to inform decision-makers to make effective policy choices, while at the same time engaging entire communities and ultimately empowering citizens (Vaughan, 2007). On the other hand, there are challenges associated with deploying expertise if there is a lack of technical knowledge regarding complex technical issues, in which case the process can become more time consuming than may be necessary (Jami and Walsh, 2014). However, today Internet technology allows ample information on a wide range of topics to be accessed more easily than before, so the public can be informed about complex issues or find experts who can participate in public hearings or parliament discussions on their behalf. Reed (2008) suggested that local and scientific knowledge can be integrated to provide a more comprehensive understanding of complex socioecological systems and processes, and utilized to evaluate potential solutions for environmental problems.

One issue with using experts for impact assessment or needs assessment studies is bias, which happens when experts try to tailor their reports towards the expectations of the respective clients. This issue was discussed by Feldman and Milch (1982), who analyzed the politics of airport planning during the 1960s and 1970s in the USA, Europe, and Canada. In their comparative analysis of the development of eight airports, including Mirabel and Toronto's second airport, they found that there were systematic discrepancies between traffic predictions used by government planners and those obtained by experts engaged by other private or public stakeholders. According to Feldman and Milch (1982), forecasters employed by airport planners have expertise and resources surpassing other participants, so they call them hired guns. This situation creates political imbalance stemming from the economic inequality between stakeholders. At the same time, it resulted in traffic forecast errors, because of the incentives provided by planners. It was preferable for government agencies to generate optimistic future travel demands and pessimistic estimates of capacity to meet projected demands, and hired guns were prepared to satisfy these preferences (Feldman and Milch, 1982). The studies ordered by governments were intended to help policy makers convince the public regarding the necessity of large construction projects, but unrealistic forecasts in fact helped sustain public protests. Although all citizen protests were initially related to land acquisitions, final decisions regarding building airports were political (Feldman and Milch, 1983; Rowan, 2017), masking the 
epistemic-democratic tension. At one side of this divide are questions regarding the abilities of 'ordinary citizens' to deal with complex matters, for which specialization is necessary, and the elitist nature of experts who build on specialization and are not necessarily neutral or objective (Krick, 2019). This economic and political tension persists today, and the growing demand for public participation as a means to strengthen the legitimacy of public policies is coupled with the need for reliable expertise (Parker et al., 2014; Krick, 2019).

\subsection{Transparency in public discourse}

Environmental problems are typically complex, uncertain, and multi-scale, affecting multiple actors and agencies. They demand transparent decision making that is flexible to changing circumstances and embraces a diversity of knowledge and values (Reed, 2008). The transparency of decision-making processes is important for achieving public trust in government decisions, which can happen if participatory processes are perceived to be transparent and conflicting claims and views are given serious consideration (Irvin and Stansbury, 2004; Reed, 2008). Transparency is essential for establishing the liability of decision-makers for their actions, so without transparency there is no accountability (Nuesiri, 2016). There is difficulty implementing this concept in long-term projects, like airport development. To hold accountable policy-makers who left governance over time is impractical or impossible.

In theory, public participation in policymaking should enhance transparency by definition, according to Pickering and Minnery (2012), who define public participation as twoway communication and interaction. When public input into the proposed policies goes without any response and feedback from the government, it appears as if the policy makers in the government do not care about citizens' concerns. Lack of government response to concerned citizens leads to mistrust towards government representatives, and resentment will develop over time if participants' actions and decisions are ignored (Irvin and Stansbury, 2004). Deliberative

processes, in which solutions are found or decisions are made through active debates (Pickering and Minnery, 2012), are important for enhancing transparency in agricultural land stewardship. Deliberative participatory process setting is more likely to produce an orientation of participants' views toward the common good, and therefore more likely to produce outputs more favourable to the environment (Newig, 2018). 
Another aspect of communications in global environmental management is information disclosure. Disclosing information is central to achieving various aims, including greater transparency in environmental governance (Gupta, 2010). Sometimes there is difficulty in disclosing information, particularly in fiscal transparency, because opening access to information does not ensure its proper use (Khagram, 2013). The key obstacle for achieving transparency is often weak political will on the part of government to comply with formal accountability standards (Nuesiri, 2016), or government officials are 'distrustful of civil society actors, or intolerant of what they see as illegitimate meddling in the affairs of government' (Malena, 2009).

In general, if the process does not appear to be holistic and fair, it is less likely to be accepted as legitimate (Reed, 2008; Newig et al., 2018). The overall goal of increasing transparency is that better decisions can be made and supported by the public (Reed, 2008). Thus it is necessary that civil servants are transparent about their decisions, and to provide publicly accessible lists of participants in the process, in order to allow public scrutiny of their choices (Krick, 2019). So the important strategy for constructing effective participatory practices in environmental management, in potentially long decision-making processes, is to enable transparent processes as early as possible, to build trust among the participants (Irvin and Stansbury, 2004; Savan et al., 2004; Fung, 2006).

The media play an important role in checking government activities, but in addition to increasing accountability and transparency in environmental governance, it plays another important role in the public discourse. Those who can utilize the media have a better chance of setting the narrative and shaping public opinion. In particular, if a group of citizens that protests a development project is labeled as NIMBY, it could be hard for this group to fight the accompanying stigma. Citizens have a greater chance of success if they stage their actions as 'eventful', which according to Porta (2008), are actions that have a highly relevant cognitive, relational and emotional impact on participants and observers. Those kinds of events tend to produce larger effects, not only on the authorities or on public opinion, but also on the movement actors themselves.

\subsection{Urban development issues}

Behind this story lies urban development and its first victim: agricultural lands. A longstanding feature of urban development is urban sprawl, defined by Bruegmann (2005) as low- 
density, scattered urban development without systematic large-scale or regional public land-use planning. It is happening all over the world, occurring mostly along the fringes of urban centers (Slemp et al., 2012). Currently, more than half of the human population resides in urban settlements and this number is only projected to grow (Vallance, 2014). As urban settlements expand in response to growing populations, surrounding areas around cities are targeted for various development projects. Brueckner (2000) defines urban sprawl as the excessive spatial expansion and infringement of cities on agricultural land. The limitation of this definition from the environmental perspective is that it does not account for the damage sprawl causes, like air and water pollution, which Brueckner acknowledges but calls these market failures. Modern suburban or ex-urban development is not identified as a problem for many suburban dwellers, because it does not severely affect their quality of life (Richardson and Gordon, 2004), and increases the connectivity among urban habitats (Bruegmann, 2005). Sprawling patterns are usually associated with high-income rates, so that they have lower crime rates than large cities (Frenkel and Ashkenazi, 2008). For Gordon and Richardson (1997), the main benefit of sprawl is that it is the outcome of free-market and consumer preferences that maximize the overall welfare of society.

An alternative to urban sprawl is the concept of compact development, characterized by more dense populations. Ewing and Hamidi (2015) define compact development as any urban expansion that does not conform to the patterns of leapfrog, strip or single-use developments. One of the variants of compact development is called smart growth. The Ontario Ministry of Municipal Housing (2002) formed the Smart Growth Panels to create Smart Growth Plan. It is not clear if compactness will offer more benefits with fewer costs than urban sprawl in the future, because urban development is behind both of these concepts (Neuman, 2005; Ewing and Hamidi, 2015). One way of measuring the sprawl is based on the population and jobs distributions (Frenkel and Ashkenazi, 2008). Since successful airports are considered strong drivers of economic growth, if promised jobs from the Pickering Airport materialized in the vicinity of the future Seaton community, this development might not be characterized as sprawl. This is in line with the theory that market forces should define planning and land use and that the government planners should not be in the way (Richardson and Gordon, 2004): if the sprawl happens because people are looking for more space, fresh air, more privacy, less crime, why not allow developers to market all this for new residents as a whole package? One difficulty with this 
theory is that it does not address the issue of limited resources that are supposed to sustain uncontrolled urban growth.

\subsubsection{Ecological impact of urban sprawl}

The notion of unlimited resources for human development disregards important aspects of life on earth. Some of the negative aspects of urban sprawl include increasing energy consumption through encouragement of the use of private vehicles, causing traffic congestion and air pollution (Brueckner, 2000; Johnson, 2001; Frenkel and Ashkenazi, 2008). One of the market failures Bruckner (2000) discusses is related to the social value of open space, which is usually not taken into account by developers when land is converted to urban use. While it is questionable if these problems can be alleviated by emerging technologies and use of renewable energy (Lang, 2018), the problem of irreversible damage to ecosystems pertains. In general, the sprawl leads to increased pollution, simultaneously fragmenting non-urban habitats, particularly forests and grasslands, threatening biodiversity, and causing soil degradation (Johnson, 2001; Terando et al., 2014; Salvati et al., 2014; Dupras et al., 2016).

Soil destruction is one problem of urbanization that is often ignored by advocates for development. If prime farmland is destroyed, it is usually lost forever. Even if part of the developed land is reclaimed for farming later on, Du et al. (2014) argue that it does not ensure the same level of food production. Canada has only limited resources when it comes to top-soil farmland. If it paves the farmland to solve transportation problems expected in the next 20 years, how is the food going to be grown around large cities in 50 years? Large cities are already on the path of unsustainability, due to their reliance on fossil fuels (Lang, 2018). Preventing the loss of agricultural land and controlling urban sprawl without suppressing economic development are common problems constantly faced by various communities around the world (Bengston et al., 2004; Hawkins and Wang, 2012; Xi et al., 2012; McGranahan et al., 2016). 


\section{Chapter 3 - Methodology}

In this research, I will examine the public engagement in land use policy and the protection of agricultural lands to find out if public consultations are useful and needed in the decision making process. To determine the answer to this question, I will employ the qualitative research methods of a literature review and archival and documentary research. The review of the literature on the Pickering Airport accumulated over time and will help identify key arguments made to explain why there was such a long delay in the process. The review of the literature will be complemented with the archival research of historical records and documents from 1972 to the present to reassess previous conclusions. These methods are considered the most suitable to investigate an ongoing case with such a long shelf life, because they allow the researcher to gain insight into the history of the FLP. This research is expected to reveal the connections and influences of various stakeholders in the Pickering Airport development, and provide a way to reassess the importance and meaning of the events and actions of various stakeholders.

The literature written about this case consists of several books, journal articles and two theses. To complement this data, the archival research method is integrated, where data are collected through historical, archival and documentary research. These methods are commonly employed in the social sciences and humanities, providing viable and sophisticated tools for researchers that can be employed effectively in singular or mixed method studies (McCulloch, 2004; Das et al., 2018). There is an overlap between archives and documents because documents are considered as more complex forms of archived data, which are insightful and rich data sources (Barlow, 2015).

I analyze and compare data from different sources, such as government archives, civil groups' documents, as well as news coverage of important events, and consult literature about the early Pickering development. By examining various sources of information, it is possible to look at the data from different angles. This is important because different types of documents can highlight different aspects of the same story and also indicate potential biases (Barlow, 2015). Testing different kinds of documents against each other can help truth to emerge, and can increase the quality of conclusions (McCulloch, 2004). This testing is not to validate the quality of data but to evaluate insights drawn from different sources in order to gain a deeper and clearer understanding of the case investigated (Taylor and Bogdan, 2016). Iterative and careful reading 
of documents is employed to obtain the meaning and significance of events and actions of various actors in this story and its socio-historical significance in particular (Hill, 1993).

The limitation of historical research when gathering and analyzing data is that some documents are not accessible, and some are probably lost. In addition, some documents might privilege particular stakeholders, and may not reflect all public consultations. Consequently, there is no assurance that all available data represent a complete set of data, which puts some limitations on the conclusions that can be drawn from the research.

\subsection{Data}

This study relies on publicly available data from federal and provincial governments, civil society groups, newspapers and journal articles. Public record documents include scientific/technical reports produced by government agencies and consultants, as well as minutes and transcripts of legislative activities. Some of the documents are found on the Canada Gazette and Transport Canada websites. The Library of Parliament provides online access to Canadian Parliamentary Historical Resources that cover debates and committee activities in the Senate and House of Commons before 1994. These documents are freely accessible online and can be searched as text, but can only be accessed and downloaded as images one at a time. The federal parliament documents pertaining to the period after 1994 can be accessed through separate interfaces for the Senate and House of Commons online portals and downloaded as pdf files. The Legislative Assembly of Ontario also provides online access to a large set of policy decisions, debate transcripts, committee documents, orders and notices from 1975.

Some of the documents and reports for this research are found in the Ryerson Library, which also grants online access to the ProQuest database for Ryerson scholars. This database provides a large body of newspaper and magazine article archives that can also be searched and accessed through the portal of Ryerson University Library and Archives (RULA). The period from 1972 to the present is covered thoroughly not only by the Toronto Star and The Globe and Mail, but also by local GTA newspapers like The News Advertiser and Ajax or Hamilton's The Spectator. The Globe and Mail archive is 1939 to now, while the Toronto Star archive has two parts, one covering 1971-2009 and the other from 2009 to the present. Older news articles are accessible as images, which could be downloaded and converted into pdf or text documents, while newer articles are provided in html or pdf form. Other newspapers have shorter coverage: 
The News Advertiser is accessible from 2003. The Pickering Local History Collection's digital archive holds around 400 local newspapers, documents and monographs, digitally saved and searchable as text. A lot of the artifacts in this collection are related to news coverage by local papers and publications, so there is an overlap with other online databases.

Online archives from several civil organizations are available, namely from LOL, Green Durham Alliance (GDA), and Transport Action Ontario (TAO), which actively participate in the recent Pickering development. Their archives contain newsletters, flyers, submissions to federal and provincial governments, and their own research documents and analyses. The POP archive is not accessible online, but the group activity is very well documented in literature written by scholars and participants in the protests against the airport.

Hector Massey and Charles Godfrey published a book entitled People or Planes within six months of the first POP meeting in March 1972. Sandra Budden and Joseph Ernst wrote The Movable Airport: The Politics of Government Planning. Godfrey, Massey and Budden were POP members, while Ernst participated in protests against the potential airport location in Orangeville. In 1979, the third book by POP member Walter Stewart emerged: Paper Juggernaut: Big Government Gone Mad. In the following years, Elliot Feldman and Jerome Milch conducted technical and political analyses of three airport projects in Canada of that time and published two books: Technocracy versus Democracy: The Comparative Politics of International Airports in 1982, and The Politics of Canadian Airport Development in 1983. Victor Thompson, who was also a POP member, defended his master's thesis, Workings of a Protest/Pressure Group in Attempting to Thwart a Major Project of a Senior Level of Government, at York University in 1994. Michael Rowan defended his PhD dissertation, Crash Landing: Citizens, The State and Protest against Federal Airport Development, 1968-1976, in 2019 at McMaster University. Based on his analysis of the Pickering case, Rowan also published an article in Canada's Urban History Journal, titled 'On Their Knees': Politics, Protest, and the Cancellation of the Pickering Airport, 1972-1975. The literature provided insights into the early Pickering development and helped in understanding the chronology and significance of events.

\subsection{Analysis}

All information is systematically gathered to provide more detailed chronology, which helps in identifying relevant events and actions of government and CBEOs. The chronology 
allows key events and outcomes to be weighted according to their significance with regard to the question posed by this research. After timeline sorting, the timing and outcomes of key events are compared according to their significance regarding important government decisions and civil group activities. The comparison of documents related to significant events helps in gaining insight into the level of transparency, collaboration, and civil representation in policy development, as well as to evaluate how science was integrated into the decision-making process.

This qualitative research method is based on analysis of documents from various sources. It allows the drawing of conclusions from multiple sources of evidence to seek convergence and corroboration of conclusions. By comparing government debates with news articles or published CBEO reactions, every attempt is made to reduce and eliminate bias. Careful consideration regarding the quality of sources is taken, for example to distinguish between opinionated articles and independent news reports, which provide more credibility and objectivity of results. This is accomplished by combining and comparing analysis from different sources: government reports, different analyses of important events, and newspaper articles when available. 


\section{Chapter 4 - Protecting food resources: battles for Pickering lands}

Key events for understanding of all the political, social and economic complexities of the FLP story are listed in Table 1.1. In general, the history of the FLP saga could be divided into four periods: (1) the period before the announcement of the airport plan in 1972; (2) the period of intense public resistance from 1972 to 1975; (3) an apparently 'calm' period from 1976 to 2013; and (4) the period from 2013 to the present. The period from 1972 to 1975 is the most dynamic in terms of public participation in land-use planning. While the protests were ongoing, two books were written by participants in those events (Massey and Godfrey 1972; Budden and Ernst, 1973). In the following years, several technical, economic and political analyses have been published in peer-reviewed journals (Abouchar, 1978; Borins, 1979, Rowan 2017), three books (Stewart, 1979; Feldman and Milch, 1982; 1983) and two theses (Thompson 1994; Rowan 2019). In the next chapter, I will review the relevant literature on Pickering, after presenting how this story unfolded.

Table 4.1 Important FLP events

\begin{tabular}{|l|l|}
\hline 1968 & $\begin{array}{l}\text { The year that the federal government adopted a plan to expand Malton, } \\
\text { and after six months it announced that Malton would not be expanded } \\
\text { and that the search for a new location would be undertaken. }\end{array}$ \\
\hline 2 March 1972 & $\begin{array}{l}\text { The Pickering Airport and the North Pickering Development } \\
\text { Project announced by Ottawa and Ontario, the next day POP takes off. }\end{array}$ \\
\hline $1972-1973$ & $\begin{array}{l}\text { POP publicity stunts: funeral of Mother Nature, Democracy and } \\
\text { Pickering Township, Ontario's last 'public hanging', and flying over } \\
\text { parliament in Ottawa in the middle of winter. }\end{array}$ \\
\hline $1972-1973$ & $\begin{array}{l}\text { The Swackhammer Hearings under the Expropriation Act commenced } \\
\text { at the end of 1972, early next year the report was made public. }\end{array}$ \\
\hline $1974-1975$ & $\begin{array}{l}\text { The Airport Inquiry Commission (AIC) under Judge Gibson was } \\
\text { established, and the report made public in Jan. 1975. }\end{array}$ \\
\hline 1975 & Mirabel opened for passengers \\
\hline Sept. 1975 & Premier Davis decided that Ontario would not provide the infrastructure \\
\hline
\end{tabular}




\begin{tabular}{|c|c|}
\hline & $\begin{array}{l}\text { for the airport shortly after provincial elections. Immediately after, } \\
\text { Prime Minister Trudeau canceled the plan indefinitely. }\end{array}$ \\
\hline 1995 & VOCAL: Voters Organized to Cancel the Airport Lands was formed \\
\hline 1998 & $\begin{array}{l}\text { The government announced that Pickering would be an airport site. The } \\
\text { Order Declaring the Pickering lands as an Airport Site was finalized in } \\
\text { 2001, followed by New Pickering Airport Site Zoning Regulations in } \\
\text { 2004. }\end{array}$ \\
\hline 2004 & $\begin{array}{l}\text { The Greater Toronto Airport Authority (GTAA) presented its Pickering } \\
\text { Airport Draft Plan to Transport Canada, demoting the future airport to } \\
\text { the general aviation airport to be built in } 2012 \text {. }\end{array}$ \\
\hline 2005 & LOL was formed, around the time the Mirabel closed for passengers \\
\hline 2011 & The Needs Assessment Study report by (GTAA) was released. \\
\hline 2013 & $\begin{array}{l}\text { Finance Minister Jim Flaherty disclosed the plan for developing the } \\
\text { Pickering Airport to be operational sometime in 2027. The transfer of } \\
\text { surplus FLP lands to the RNUP was announced at the same press } \\
\text { conference. }\end{array}$ \\
\hline $2015-2017$ & $\begin{array}{l}\text { Two instalments of around 9,500 acres of land were transferred from the } \\
\text { FLP to the RNUP. }\end{array}$ \\
\hline 2016 & $\begin{array}{l}\text { The Independent Advisor to the Federal Minister of Transport, Dr. } \\
\text { Polonsky's report 'Jet and Jobs' released by TC, and KPGM was tasked } \\
\text { to conduct Aviation Sector Analysis. }\end{array}$ \\
\hline $2016-2018$ & $\begin{array}{l}\text { LOL incorporated in order to fund the study regarding agricultural } \\
\text { potential of the FLP, which was finished in April } 2018 .\end{array}$ \\
\hline 2019 & $\begin{array}{l}\text { Two-thirds of the KPMG study finished, but the government would not } \\
\text { release the results before it had a chance to review the final report. }\end{array}$ \\
\hline
\end{tabular}

\subsection{Choosing Pickering for an airport site}

In the late 1960s the federal government started planning for a second major Toronto airport because of the increasing influx of passengers. In August of 1968, the federal government 
announced a plan to expand the Malton Airport to meet the future air transportation needs of the Toronto area (Borins, 1979). This decision was strongly opposed by local residents, organized around the Society for Airport Noise Abatement (SANA) and by the end of 1968 the federal government made a U-turn, and started to search for a new airport location. The plan to build a new airport elsewhere prevailed because expanding Malton was considered politically too costly (Massey and Godfrey, 1972; Stewart, 1979; Feldman and Milch, 1983), even though the plan to expand Malton was superior to that of building a new facility (Feldman and Milch, 1982). As the Ontario government relied on MP support from Etobicoke and Mississauga riders who would be affected by the expansion, this plan was not pursued since the idea was deemed 'not saleable' to the province during the internal deliberations of the federal government (Stewart, 1979). According to Massey and Godfrey (1972), this was an extreme government reaction to objections of the residents around Malton, who were against the noise increase associated with airport expansion, but were not against any development due to possible job opportunities. Anyhow, the federal government assumed that any expansion of the Malton Airport to handle air traffic would be unacceptable (Ontario Government, 1972).

Following the cancellation of the Malton Airport plan, in the next three years further studies were conducted regarding future passenger loads and how a new airport would impact the region. The focus was on four locations in Southern Ontario. These four locations were studied because they were suggested as suitable airport locations by previous analyses, and because initially, the Ontario government wanted studies to cover all possible directions of the future airport with respect to Toronto. A report by Gerald Hodge on regional impact (Ontario Government, 1970b) rated Orangeville (northwest) and Lake Scugog (east) as more preferable airport sites compared to Guelph (west) and Lake Simcoe (north). However, after a new regional development concept called Toronto-Centered Region (TCR) was devised by the Ontario Government (1970a), the province started pushing for a location to the north-east of Toronto. The TCR concept identified urban development west of Toronto as a problematic, and recommended spurring it eastward (White, 2016). According to an analysis performed by the Ontario Government (1972), the main criteria for selecting the site of the airport was its impact on the TCR. Because all four locations listed above had some pros and cons, the search continued, and somehow Pickering Township (northeast) and Beverly Township (southwest) emerged as top contenders. Orangeville as a top candidate was disqualified after it was disclosed 
it would have winter precipitation problems and citizens started to protest (Budden and Ernst, 1973). The other three top contenders were abandoned because they were either considered to be too costly, too far, or in a direction that was incompatible with the TCR development plan. Regarding the traffic forecast, the numbers from government predictions for the year 2000 were fluctuating from a high of 96 to 196 million passengers, to a low of 43 to 60 million passengers (Feldman and Milch, 1982). Hodge's report was critical about these estimates and questioned how they were obtained.

At some point between 1970 and 1972 the Pickering location emerged as the preferred location, although it was excluded as a possible site from the list of more than fifty locations considered earlier in the process. Many details about the decision-making process preceding the announcement in 1972 are reported by Stewart (1979) and Thompson (1994), but even they do not have an explanation for why and how Pickering emerged as a top contender for the airport site. At one point it was found that there would be a major airspace conflict between Malton and Pickering. Then, in the winter of 1971, a few months before the announcement, this obstacle went away (Stewart, 1979; Thompson, 1994).

Another important factor in the decision-making process was the report from the Ontario Department of the Environment in February 1972 titled, 'Proposed Toronto Airport II: Environmental Impact Study'. In that report the soil quality in Pickering was graded as better than in Beverly, and that was the only issue for which Pickering was considered a worse airport location. Everything else, from farms to wildlife, appeared to be less important in the Pickering case. Farms in Beverly looked more modern and successful than Pickering's farms, and the government concluded there would be less social and environmental disruptions if Pickering was chosen for the airport (Ontario Government, 1972). POP experts complained the report was shallow and rushed, made only to justify a location to which the Ontario government would not object (Stewart 1979, Thompson 1994).

After three years of going back and forth on various locations, the federal government was eager to choose a site that would be 'suitable' for the Ontario government, so Beverly was dropped. The Ontario government was strongly opposing a westward location that had the potential to undermine the goals of the TCR plan, and the province was consistently evaluating proposed airport sites in terms of how they would help control urban sprawl to the west of Toronto (Borins, 1979). So the main factors that left Pickering as the last candidate were the 
federal government's desire to have a new airport at any location and the Ontario government's desire to push urban development to the east (Stewart, 1979; White, 2016).

\subsection{The first battle}

On March 2, 1972 the federal and provincial governments jointly announced that they signed an agreement to build a major six-runway international airport. This required expropriation of 18,600 acres (7,530 ha) of Class 1 agricultural land. The provincial government was tasked to provide the supporting infrastructure for the airport, such as roads and sewers (Winsor, 1972; Abouchar, 1977). Local residents immediately started organizing to protest this decision, and the very next day formed the group People or Planes (POP) (Massey and Godfrey, 1972). The expropriation notices started to arrive soon afterward, affecting many historical buildings. In addition to concerns for expropriated property, heritage structures, agricultural land and the environment, citizen outrage was additionally fueled by the notion that the government was secretive and not transparent. There were no public consultations regarding the selection of the Pickering site and the need for the airport, and the government was reluctant to provide such documents (Stewart, 1979).

POP sprang into action to oppose the expropriations and airport project on several fronts: through legal action, with a media campaign, and by starting its own research on technical issues (Thompson, 1994). It was also trying for the federal and provincial ministers to pay attention to their concerns, by engaging in unorthodox ways of grabbing public attention. One of these events aimed to mock the government for compromising environmental, political and social priorities. POP supporters organized a silent march in black robes through downtown Toronto to lay three coffins in front of the Legislature. Black wooden coffins labeled Mother Nature, Democracy and Pickering Township represented the destruction of farmland and wetlands in the area, the government's disregard for public priorities and the lack of transparency in the decision making process, and ruining of the rural community of North Pickering.

Many details regarding media coverage of the protests and POP strategies to engage the public are given by Thompson (1994) and Rowan (2019). A key performance for the public and media that had a measurable impact was the staged hanging of Prime Minister Pierre Trudeau's and Premier Bill Davis's effigies in June 1973, shown in Fig. 4.2. The purpose of this exercise was to get the attention of the provincial politicians they were trying to reach, because POP 
realised that the federal government would be less receptive to their arguments against the airport. According to Michael Robertson, a POP member participating in these events: 'Within a week, we had a meeting with Bill Davis and his cabinet, where we presented our research, which started to turn the tide against the airport' (Casey, 2012).

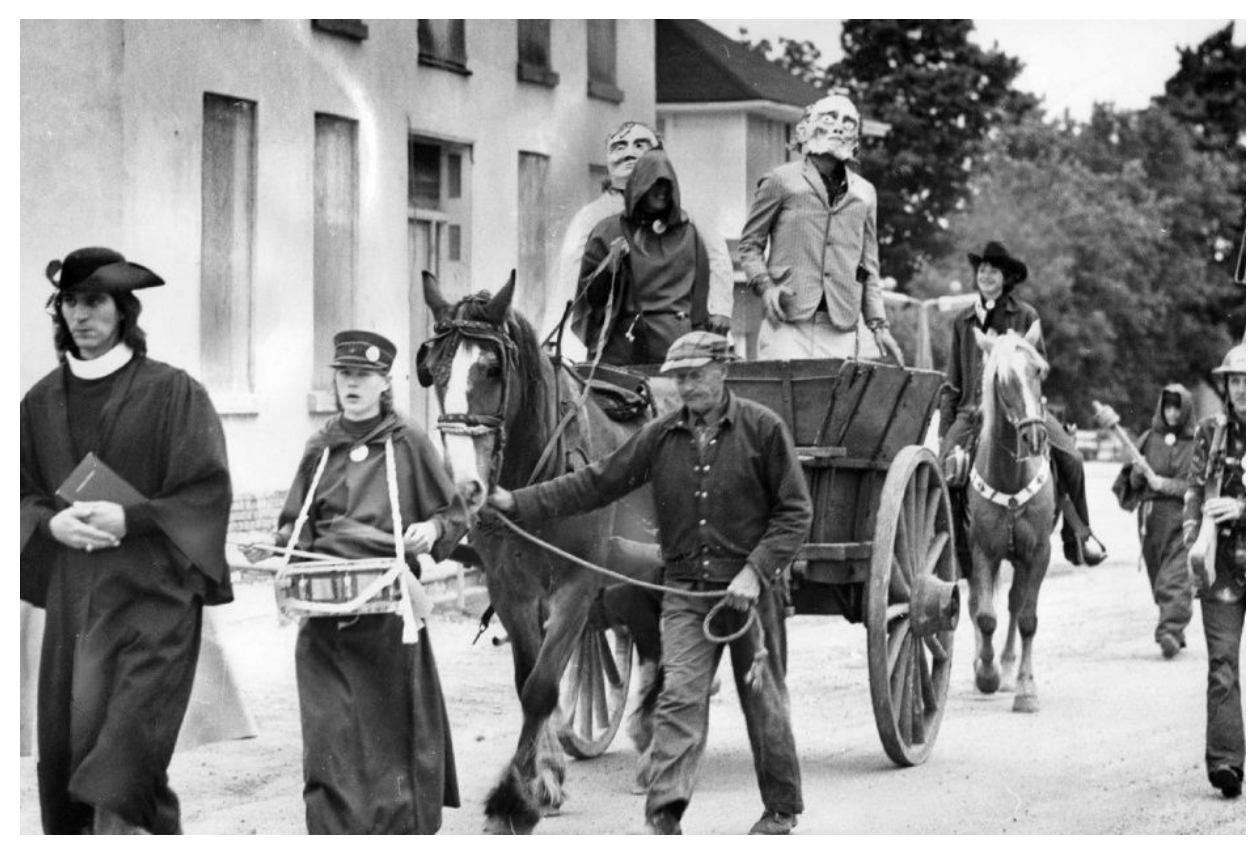

Figure 4.2. POP performing 'the last public hanging' in Ontario in 1973

The key message that POP was trying to convey to the public and politicians is that there was no need for a new airport in the Toronto area, based on its own research. In addition, the selection of the Pickering site was not supported by any technical studies prior to the March announcement (Feldman and Milch, 1983). The group was not alone in the battle against the airport; it had aligned itself with the Confederation of Resident and Ratepayer Associations of Toronto. The Canadian Airline Pilots Association was active in its opposition to the plan, because pilots also did not see a need for any new facilities.

The federal government did not want to have any public discussions regarding the location, or the need for a new airport, but it was obligated to address the expropriation concerns of citizens, under the Expropriation Act (1970). Consequently, the Swackhammer Hearings started at the end of 1972. The obligation was only to hear objections regarding expropriated property, not the underlying project, but thanks to hearing officer, J. W. Swackhammer, many 
objections to the project ended up in the report (Government of Canada, 1974). The report was graded as fair by POP (Stewart, 1979; Thompson, 1994), and the federal government could not ignore it, since it included a criticism regarding traffic forecast made by Dr. Hodge who was a government witness. Shortly after the Swackhammer report was made public in January 1973, the federal government followed with a public inquiry to investigate the need for the new airport to satisfy the pubic, and to legitimize the project by allowing a form of dialogue between the state and its citizens.

The Airport Inquiry Commission (AIC) was formed with a delay, and commenced about a year later, with the mandate to consider only new evidence (Feldman and Milch, 1983). The chair of the commission was Judge Hugh Gibson, who introduced hearing restrictions regarding the witness qualifications and expertise that placed a financial burden on the POP to engage legal representation, which it could not afford in the long run (Thompson, 1994). So it became clear that this was only made to placate the public until the government was ready to start construction. The inquiry did not question the need for the new airport and it sided with government experts that the new airport was needed (Borins, 1979). However, it made a confusing two-fold recommendation to the government: (1) build the international airport in Pickering and supporting infrastructure, but also (2) build an additional runway to expand the Malton Airport, to facilitate traffic until Pickering is operational (Transport Canada, 1974). Feldman and Milch (1983) claim that the AIC accomplished something that has not been done before: for a short period it united both the opponents to the Pickering Airport and the opponents to the expansion of the Malton Airport.

The public hearings lasted for more than two years and did not seem to bring the Pickering Airport protesters and federal and provincial planners any closer. After the AIC report, protests intensified while the federal government was preparing for the airport development in the summer of 1975. According to the polls taken after the AIC report, the public around metro Toronto was against the airport (Rowan, 2019), and Premier Davis asked the Prime Minister to postpone airport construction until after the provincial election in the fall of 1975. This election proved to be a pivotal moment that changed the constellation of political power in the provincial government. POP leader Dr. Godfrey won a local seat, and Conservatives lost their majority in the Ontario Parliament. Consequently, Premier Davis refused to build the infrastructure for the airport, and the next day Prime Minister Trudeau decided to put the plan on hold indefinitely. 


\subsection{The plan on the shelf}

While the decision to put the plan on the shelf was still relatively fresh, the Ministry of Transportation (Transport Canada) and Ontario Ministry of Transportation and Communications jointly started a new study, the South Ontario Multimodal Transportation Study (SOMTS), to look at all modes of passenger transportation in southern Ontario in late-1975. The Federal Minister of Transport at that time, Otto Lang, required that the option for the Pickering Airport must be maintained during the term of the study. Because the SOMTS lasted longer than two years, the press was speculating that the outcome was known and that congestion problems at the Toronto International Airport were manufactured to justify it, which Mr. Lang denied (Hakala, 1977). In addition, during parliamentary questioning, Ontario Minister James Snow denied that the province changed its stance on servicing the infrastructure for the airport, but stated that this position would be re-evaluated if the study showed that the new airport was needed (Ontario, Legislative Assembly, 1977). Because this was a technical study carried out by the technical representatives of two ministries, Mr. Snow indicated that no public hearings were considered, and also refused to make a commitment for the public input into the study. It took four years for the study results to be released, and it concluded that with additional terminal capacity the Malton Airport would be sufficient to handle the traffic for at least the next ten years (Department of Transport, Canada, 1979). Another conclusion of this study was that the longterm option to have an airport in Pickering should be protected by zoning regulations. Shortly after, Transport Minister Don Mazankowski solicited input from air travel businesses for ideas about Pickering lands, and offered more studies (Daw, 1979).

In the following years there was not much news regarding the airport, and although the plan appeared dormant for almost 20 years, the demolition of homes and heritage buildings continued. This period was identified by the LOL as hiatus years. For example, in 1983 TC claimed that the third terminal at Malton would be unnecessary until 1990. Nevertheless, two years later Ottawa released the Central Ontario Area Aviation Master Plan, which called for a reliever airport in Pickering to handle Malton's general aviation traffic up to 2000, and later to be transformed into a major international airport by 2020. In addition, it was contemplated in Ottawa that the half of the expropriated lands should be sold (Byers, 1984). Even before it became clear to the government that there was a surplus of land, POP members were preparing 
their own plans for Pickering lands. Their efforts materialized when the Pickering Airport Lands Revitalization Committee (PARC) was appointed in 1984, which included three members of the POP. Already at that time, a proposal to use the land as a training ground for young farmers who would want to get into the farming business was floated by Dr. Godfrey ('Airport plan shelved', 1985). In 1986, the PARC report recommended selling half of the land for conservation, mostly as an agricultural preserve, and some for recreation. Even if the recommendations from this study were not formally adopted, the idea to use these lands to create a park ten years later started to materialize, as the Rouge Park opened in 1995 and eventually transformed into the RNUP under Rouge National Urban Park Act (2015).

\subsubsection{The resurrection of protests}

By the late 1980s plans for disposing of the surplus of Pickering lands started to intensify, with an outcry when Public Works offered half of the expropriated lands to Ontario and area municipalities instead of to former owners or existing tenants (Johnson, 1987). The residents were upset with the possibility that the area could be turned into a dump or new residential area, and POP again asked the federal government to create a park from the surplus lands ('Angry Pickering residents', 1987). Ottawa did not know what it would do when Pearson reached its limits, and in 1989 it started another study named South Ontario Area Airports Study (SOAAS). In 1992, Transport Canada formalized the plan to sell around 200 lots, which was modified two years later to include 2,871 hectares, without formally acknowledging that initial expropriation was an overreach. Questions of what to do with the surplus lands were circulating in provincial parliament. In 1993, the federal Liberals took power and the disposal decision was deferred, and the area returned to limbo (Armstrong, 1998). LOL believes that plans were never realized because of expected SOAAS results.

The federal government released the SOAAS report in 1995, indicating that a system of airports would be needed to accommodate aviation demands. It recommended that Hamilton, in the west, and Pickering, in the east, would be used to supplement the main hub at Pearson. Even before the public release, Hamilton airport managers had a chance to listen to the SOAAS presentation, and complained that the study was flawed, and that if the Pickering Airport was built, regulations would be need to manage competition that would eventually hurt Hamilton Airport (Arnold, 1994). The same year a POP successor Voters Organized to Cancel the Airport 
Lands (V.O.C.A.L.) was formed, and the GTAA proposed terminal rearrangement and new runways, so that Pearson could handle 50 million passengers (Airways, 2014).

In 1998, new zoning regulations for the Pickering area were brought up when the federal government declared Pickering as an airport site. It was envisioned to complement the Pearson Airport, as a regional airport by GTAA, which hoped that the facility would be ready for the 2008 Olympics if Toronto won its bid to host the event. It did not matter to residents if it was a reliever or an international airport; they did not like the idea, and Pickering Mayor Wayne Arthurs was not happy there were no consultations with the town prior to the federal announcement (Josey, 1998). Consequently, federal Transport Minister David Collenette announced the public comment period on the airport plan had been extended by 60 days.

The federal government officially declared Pickering Lands as an airport site in 2001, under the Aeronautic Act (Government of Canada, 2001), to protect the option to build the airport in Pickering, and adopted new zoning regulations in 2004. In the anticipation of airport constructions, Ottawa restarted demolition of the farmland structures in the Pickering area. Residents were ready to fight the airport again, because the plan had gained new traction since Minister Collenette declared at the beginning of 2002 that Toronto's Island Airport could be closed once a high-speed rail link was built from downtown to Pearson. Eventually, an airport would be built in Pickering in the next decade to relieve the strain on Pearson (Josey, 2002).

At the beginning of 2004 a new GTAA plan for the FLP was expected, and the GTAA was promising that there was going to be public consultation after the report was done. The leader of VOCAL believed the report was delayed so it would not be a topic of discussion during the anticipated spring federal election (Milley, 2004).

\subsubsection{A new kid on the block}

To combat new airport initiatives and protect remaining properties, LOL was formed in 2005. The Greater Toronto Airports Authority (GTAA) (2004) plan proposed a two-runway general aviation (GA) reliever airport to be built after 2012, with an option for a third runway by 2032, to handle excess traffic from Pearson. While anti-airport groups VOCAL and LOL were joining their forces, TC continued to study the need for the Pickering Airport, and contracted GTAA again in 2007. This was a clear conflict of interest because GTAA would eventually operate a new airport, and probably build it. When GTAA produced its report it was made public 
with a delay: it was received by TC in March 2010, and released in July 2011 (Greater Toronto Airports Authority (GTAA), 2010). The main conclusions appeared similar to earlier studies. The report states that the FLP should be retained for a future airport, with a rather uncertain conclusion when it will be needed: by 2027 at the earliest, or as late as 2041 . These estimates were based on projections of how surrounding airports in Waterloo and Hamilton would develop over time, and the passenger growth rate.

LOL's response to the study consisted of an extensive list of complaints, including that the traffic forecast was conducted by the party with a conflict of interest, GTAA, so no landpolicy should be adopted based on biased estimates. LOL members joined forces with Green Durham Alliance (GDA), another CBEO, to produce a memorandum for managing the FLP (Green Durham Alliance, 2012). The intention was to influence the FLP land-use policy by advocating for the creation of a land trust that would manage 18,600 acres instead of TC, without foreclosing a federal airport option.

Around that time, the decision to transform Rouge Park into the first national urban park was brewing. Jim Robb, general manager of Friends of the Rouge Watershed, lobbied in front of the Federal Standing Committee on Environment and Sustainable Development in Ottawa for the park concept. He also explained how it would be ideal for the federal lands in Pickering to be included in the park complex, since they are already owned by the government and include parcels designated under the provincial Greenbelt.

\subsubsection{Why the 'calm' period lasted so long}

After the plans for the development of the Pickering Airport were put on hold, the government inaction regarding the use of the FLP lasted for almost 20 years. So, it looked as if the FLP issue was left to fade away. One might label this a period of calm, although LOL calls the whole period of 1976 to 2013: years of hiatus (LOL, 2016). To find out why there was a long period of indecision one can look at the discussions in the federal parliament from 2011. Lloyd McCoomb, President and Chief Executive Officer at Greater Toronto Airports Authority in 2011 shed some light on the reasons behind the long delay in decision making during his testimony at the Senate (Standing Committee on Transport and Communications, 2011). He pointed out that the concept that was responsible for the Mirabel failure was supposed to be applied to Toronto's two-airport system: Pearson and Pickering. The Mirabel airport was projected to become the 
major international airport in Montreal and replace Dorval in that role. The main reason Mirabel failed is the decision to put all international traffic at one airport (Mirabel) and all domestic traffic at another (Dorval). This configuration did not work because air-carriers were hesitant to relocate, and there was no comprehensive policy for passengers traveling between two airports, or between Mirabel and Montreal (Feldman and Milch, 1982). The passenger load was much lower than anticipated at the very start of operations, because of these inconveniences, and the airport was losing money from the beginning.

The federal government did not want to repeat the same mistake, since the intent was to make a similar arrangement between the two airports in Toronto, as in Montreal. Because of this two-airport coupling, the hesitation regarding the airport in Pickering resulted from a long stagnation in decision making at Pearson, due to the political pressure from the residents around Pearson Airport who were resisting its expansion and anticipated noise increase. Thus, it appeared as if the government forgot about Pickering. It was only by the end of the 1980s that it was decided to retain the Pickering lands for a possible future airport, while proceeding with the redevelopment of Pearson Airport to the maximum extent that it could be developed (Standing Committee on Transport and Communications, 2011). The Pearson Airport expanded extensively in the 1990s, while the decision regarding the Pickering site was formalized by airport zoning regulations from 1998 to 2004.

\subsection{The last airport reincarnation?}

After the Needs Assessment Study the government continued working on a detailed land use study and management strategy that was supposed to be open for all potential uses, with the focus on economic development and environmental stewardship ('Balance is needed', 2012). In 2013, the federal government decided to scale down the project and dedicated one half of the initially expropriated land to the Rouge National Urban Park, while affirming that the remaining land would be used to build an airport in Pickering ('Responsible, balanced approach', 2013). The environmental stewardship that was promised earlier appeared to have materialized in this government decision. However, LOL did not consider this as a big government backtracking on

airport lands, because the areas that were transferred to RNUP were already included in the Ontario Greenbelt, and were never needed or indented for airport use. Another issue raised about 
this decision in the news was the transparency of the process, because the announcement appeared to surprise the province and local politicians. Ontario Transportation and Infrastructure Minister Glen Murray said he thought the announcement was only about the park land and that Minister Flaherty blindsided him with the airport announcement, tweeting later there was no cooperation between the province and Ottawa on the airport decision ('Pickering Airport announcement', 2013). However, federal Finance Minister Jim Flaherty who made the announcement claimed that it is hard to believe the province was not included in the process, and that provincial Transportation Minister Glen Murray backtracked on the joint press release a day before (Blizzard, 2013). It is fair to conclude that both federal and provincial ministers were playing politics.

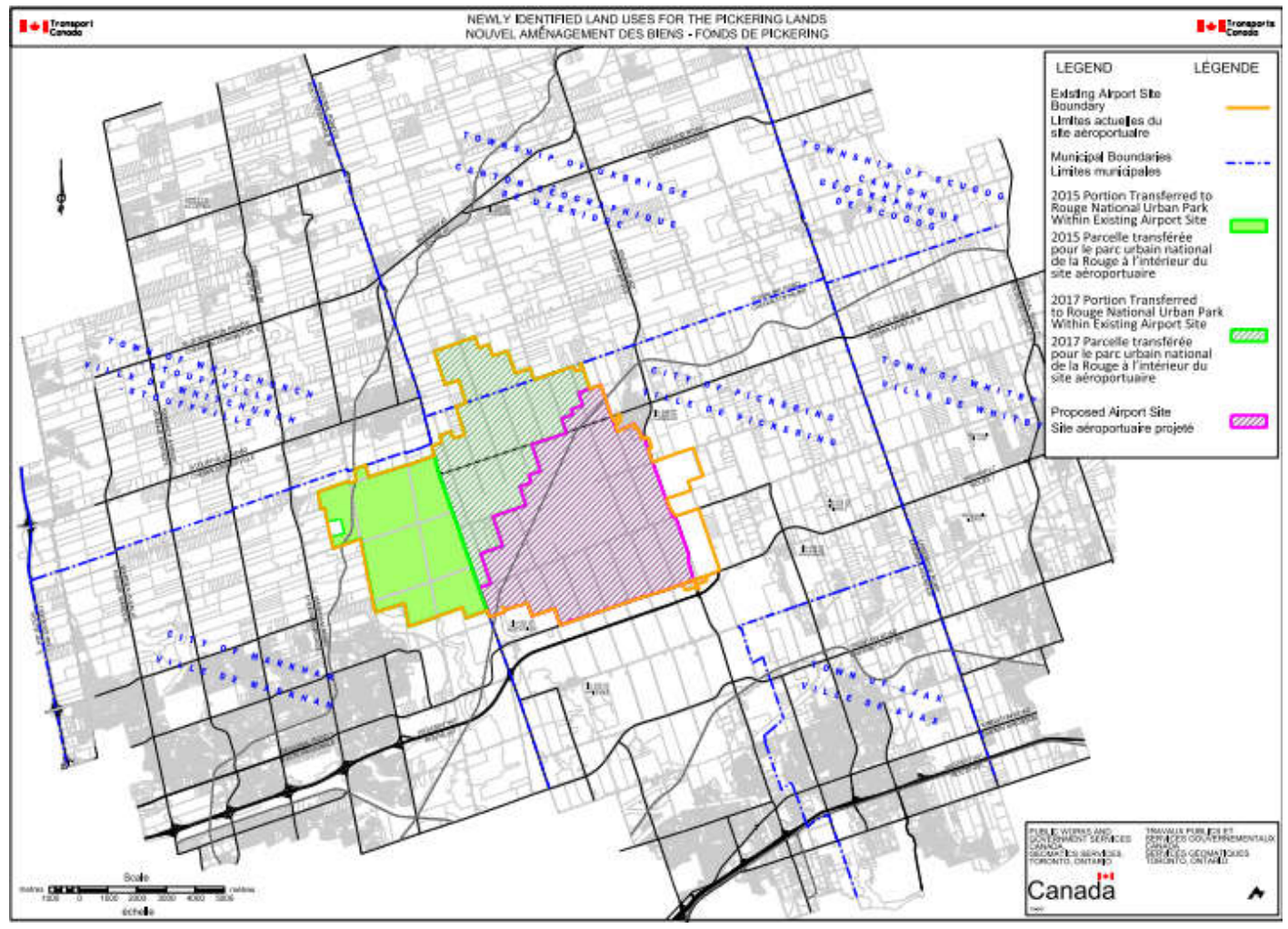

Figure 4.4. Remaining FLP lands and two parcels that now connect the RNUP with the ORM.

Figure 4.4 shows the original FLP boundaries, and two chunks of land that were transferred to the RNUP, as well as a part that is still reserved for the airport. The technicalities of the land transfer from the FLP to RNUP were formalized in 2015 and 2017 (Transport Canada, 2015), while the exact timeline for the airport construction had not been set. This is 
because the decision was based on vague predictions by the Need Assessment Study of when the airport would be needed. It is worth noting, that even with a reduction in size, the area of FLP is more than twice the size of Pearson. It was not a surprise that locals were gearing up for another fight to protect remaining prime farmland, while at the same time Transport Canada promised it would initiate a federal regulatory process to re-designate the Pickering Airport site, and update the zoning regulations. The regulatory process assumed that another round of public consultation would happen ( $\mathrm{Lu}, 2013)$.

In 2014, a citizen transportation advocacy group Transport Action Ontario (TAO) (2014) responded to the 2010 GTAA's report, in order to oppose the airport development. The main objection to the study was that a large fraction of aviation traffic in and out of Toronto is for trips within $1000 \mathrm{~km}$, which could be handled by railroads in a more sustainable way. The group assessed that the main philosophy behind building an airport that might not be needed falls under the 'Build it and they will come' notion, which assumes that passengers would eventually start to use particular infrastructure when it is provided. In addition to valuable farmland loss, TAO claims that the airport will have a major detrimental effect on the entire region including the Greenbelt lands, because of its proximity to the ORM. People who were concerned with connecting the RNUP and ORM were asking for all federal lands in Pickering to become part of a $100 \mathrm{~km}^{2}$ park. The federal lands provided a good connecting path, because the town of Stouffville already had far too much development to connect the park and ORM any other way. Prime Minister Harper did not honour these requests in full, but announced that another chunk of $\sim 5000$ acres (around $21 \mathrm{~km}^{2}$ ) in Pickering and Ajax would be added to Rouge National Park, doubling the government's contribution to the park that would have almost $80 \mathrm{~km}^{2}$ in total ('National park', 2015). The remaining 8700 acres $\left(\sim 36 \mathrm{~km}^{2}\right)$ would stay under TC jurisdiction for economic development, including a potential airport. At that time Transport Minister Lisa Raitt said she would name an independent adviser, who would meet with local interests on potential economic development opportunities around a future airport. A few weeks later Dr. Gary Polonsky was formally tasked as an independent advisor to the minister.

The study on the economic development of Pickering lands conducted on behalf of the federal government by the independent adviser Dr. Polonsky (2016) was released at the end of 2016. It was done earlier that year and the Liberal government was under pressure from all sides: from airport proponents to reveal its conclusions, and from airport opponents to finish the story 
and transfer the FLP to the RNUP completely. However, the study proved to be inconclusive: one of the recommendations was to conduct more studies regarding the need for the airport. Around the time it was made public, TC had initiated an aviation sector analysis to obtain updated aviation demand and capacity data.

TC recruited KPGM for this task, which was initially expected to be completed in 2018. KPGM is one of the largest companies in the world that engages in transportation consulting. The company profile fits into the description hired guns, used by Feldman and Milch (1982) to describe the level of expertise and economic potential of experts contracted by government planners. The goals of its study are outlined by TC in three phases. The first phase should provide an update on supply and demand forecasts for aviation traffic in Southern Ontario, to determine whether a shortfall in aviation capacity is expected in the next 20 years. The second phase should develop and evaluate options for the type of airport and its potential role in the Southern Ontario airport system. The final stage should provide an assessment of the revenuegenerating potential and economic impact of these options. In other words, the study should determine the business case for the airport. In the first part of 2019 it became clear that the study is two-thirds done, but the federal government said that it would not comment on the results until the analysis is finished.

In the meantime, LOL was active in countering government studies, and in 2017 it started to look for independent analysis regarding the agricultural potential of the FLP. The study on behalf of LOL by Kubursi and Groenewegen (2018) was finished in April 2018. It estimated that the agricultural potential of the remaining 9,000 or so acres could be north of $\$ 200$ million per year if comprehensive agricultural policies are employed. This is estimate relevant to the evolution of the FLP case, as a counter argument to the airport proponents. LOL authored a few research papers of their own, and utilized them with the agri-study to present the case for preserving the FLP as an agricultural preserve to the Standing Committee on Finance (2018), the Transport Minister, and the Minister of Agriculture in Ottawa by the end of 2018. LOL later reported that its actions and cause were supported by the Minister of Agriculture and Agri-food, and Chair of the Standing Committee on Finance. While the results of the KPGM study are expected, the discussion through opinionated press releases intensified in 2019. At the same time, TC planned aviation initiatives for the period 2019-2021 include amending the Pickering Airport Site Zoning Regulations. The proposed amendment is an acknowledgment that the 
zoning regulations from 2005 do not reflecting the fact that only a portion of the designated lands would be required for a future airport. Public consultations for interested stakeholders were 60 days. According to the TC website for Aviation Initiatives, the target date for the amendment publication in the Canada Gazette, Part II, is May 2019.

\subsection{POP, VOCAL, LOL}

POP was a diverse group of citizens comprising of local residents, as well as journalists, doctors and celebrities, and some media described them as elite (Thompson, 1994). The chair, Dr. Godfrey, was a well-known doctor from Toronto, with no direct stake in the land that was expropriated. This played well in POP's media efforts to avoid being labeled as NIMBYist, because residents initially opposed the airport project to protect their properties. A part of the public was not on the side of protest because in some news reporting POP was painted as fighting the progress merely because of expropriations. However, the POP management recognized early on that they needed to establish a different narrative: that this is a fight to preserve fertile lands and that big government does not have a reason to build the airport in the first place. So they turned environmentalist, and aligned themselves with other groups that were fighting for environmental protection and against uncontrolled urban development (Borins, 1982; Rowan, 2019).

Using humour, supported by serious research, they were able to frame the narrative and swing public support, enough to successfully take part in public deliberations, and eventually in the election process. Thompson (1994) attributes their success to Dr. Godfrey's management style. He was patient and democratic during internal debates, but once the votes were counted, he did not allow for dissent regarding adopted plans for actions. So, some of their media stunts that had a large impact also resulted in membership losses. According to Thompson (1994), the hanging of dummies of federal and provincial leaders was not acceptable to everyone, so some people abandoned their membership. Figure 4.2 shows how 'the last public hanging in Ontario' was staged. One spectacle not planned in advance was performed by Mike Robertson, a professional hand-gliding instructor who lived on the land. He launched his glider above Parliament Hill in the peak of the winter of 1973, and landed on snow in front of journalists,

picking up more coverage than the federal officials whom media people awaited (Casey, 2012). Many of POP's actions can definitely be described as eventful, which was a significant factor in 
gaining public support (Porta, 2008). POP members' engagement in environmental protection continued after the project was stopped. For example, several members were participating in the PARC committee; some joined other groups like GDA, which was originally named Green Door Alliance. Some members helped in the creation of V.O.C.A.L.

V.O.C.A.L. leader, Stephen Frederick, a businessman from Claremont, was organizing protests for about 10 years. There is not much information about the group in news coverage from 1998 to 2005, and the group coexisted and collaborated with LOL for a year or so. LOL was formed at the time when the new FLP zoning regulations took effect in 2004 and Transport Canada was gearing up to implement the Pickering Airport Draft Plan provided by GTAA (2004). The plan called for a new airport in Pickering to be operational in 2012. Regarding this plan, Stephen Frederick stated that he is not against the airport if there is a need for one, but he opposed to the construction before it was actually needed, which was not the case in 2004 (Milley, 2004). As TC restarted evictions and demolitions on the lands, LOL's initial task was to survey and protect remaining buildings, and stop evictions. Today, LOL is conducting its own research, engaging media, and trying to convince the federal government to preserve the land for farming. This is an ideological difference between two CBEOs, the V.O.C.A.L. chair would allow for airport development while LOL adamantly opposes any airport.

Some airport proponents are trying to exploit the LOL opposition to the plan to paint them as citizens ill-considerate regarding wider public need for progress and jobs, worrying only about cheap renting of properties they are enjoying on federal lands. LOL is following the same strategies as POP to avoid NIMBY stigma (Dear, 1992). One of them is to reach out to members of federal and provincial parliaments as often as possible. Around the time of the last airport reincarnation in 2013, LOL organized a bus tour for environmentalists, reporters and several federal opposition MPs, to show-case how urban development crawled to the edges of the FLP ( $\mathrm{Lu}, 2013)$. This exercise was to show what would happen to the farmland it opened to developers, even for a small airport. LOL advocates for farmland preservation through a land trust rather than returning the land to the original owners. If the airport zoning restrictions are removed and the land parcels are back in private hands, this would greatly benefit developers.

For LOL, food is a growing concern. Recently it was revealed that there is not enough land used for farming in Ontario to feed its growing population (Atkinson, 2019) So, rather than 'flying' over Parliament Hill to grab media attention, LOL finds its strength in publicizing its 
research conclusions in the media, while also advertising its main findings to interested politicians, and collaborating with like-minded organizations in the GTA. The list of groups and organizations that are concerned about farmland and food production on LOL's web page is quite long. In addition to ordering the agri-study, LOL has conducted its own research on multiairport developments in North America, to combat the perception that airports are job providers by default. It found that additional airports built around established major airports are only successful when the government intervenes and forces consumers toward the second airport (LOL, 2017). Even as LOL is following the same strategies as POP, its social potential is reduced because the population has been in decline for so many years due to Transport Canada land-use policies.

\subsubsection{The social cost of land mismanagement}

The demolition of expropriated properties started almost immediately after the AIC report in 1975. With the decline in population, social problems started to manifest when abandoned homes were vandalized or burned down. In 1981, the Pickering mayor asked the federal government to clean the land that became a 'slum', because of its unresolved status. He was also concerned regarding the taxpayers cost due to overtime for firefighters, who had to attend frequent fires of boarded properties. The story was repeated 15 years later. A report from the Toronto Star in November 1995 stated: 'Brougham area resident are feeling the heat as more than 10 vacant buildings on federally owned Pickering Airport lands have been torched in recent months'. Several properties burned within six months in 1995-1996, and the Ontario Fire Marshall later determined that three were caused by arson. The POP chairman also complained that the area became a 'rural slum', because farmers abused leasing properties since they did not have any stake in the future of the land ('Airport plan shelved', 1985).

New businesses in the region were also affected by the uncertainty of the airport development that was in an unresolved state for a long time. Even with this risk of unpredictability, some decided to move into the 'ghost town' of Brougham, at the intersection of Highway 7 and Brock Road. At some point, there was a proposal to convert 2000 acres of the FLP for a garbage disposal site by Durham municipality, which was supposed to be a part of a large industrial park. Of course, local residents were protesting the possibility of pollution from the garbage dump. The discussions on this subject continued for several years, and Metro Works 
urged the federal government to use Pickering lands for the Metro Toronto garbage disposal ('Use Pickering Airport', 1988). Although the federal government refused to do that, this and other initiatives to develop the land and use it for something other than agriculture were upsetting residents and keeping them on edge. The effect of the 20 -year political battle on north Pickering can be gleaned from Urban Affairs reporter Craig McInnes's description of the area in 1992: '...it looked as a hit from neutron bomb: the buildings still stand, but the life is gone'.

In 1996, the government admitted to the mismanagement of the land and properties. Assistant Deputy Minister of Public Works, Ranald Quail, stated that the Department of Public Works and Government Services Canada, as the official landlord and property agent should eliminate its 'slum landlord' image. For years Ottawa was not investing enough in property maintenance, and one-year-lease tenants did not have any incentive to fix roofs or fencing. After that admission, the leases were extended to three years, and annual spending on upkeep increased to $\$ 3.5$ million from around $\$ 1$ million annually in previous years (Armstrong, 1998). An additional burden to Pickering residents was repeated re-incarnations of the airport prospect; they were 'sick and tired' of the talk about future airport every time the topic resurfaced. Particularly when the zoning regulation to protect the airport option in June 1998 was announced, and federal Transport Minister David Collenette stated that 'residents have nothing to worry about for the next 15 or 20 years'. However, evictions and the demolition of properties on the expropriated lands intensified after new zoning took effect.

One of the first LOL's actions in 2005 was to march in Brougham to protest the schedule to evict families and demolish buildings. LOL applied POP-school activity and hung a dummy representing the GTAA, demanding a moratorium on the demolitions and evictions from federal airport lands ('Protestors hope', 2005). There was a temporary relief in this schedule thanks to the efforts of MP Mark Holland, who stated that the government was mistreating tenants. Public Works eventually resumed wrecking empty buildings, and one local resident was arrested for protesting (Milley, 2005). Several years later Public Works lost the right to manage the lands, but several buildings were torn down in 2007.

Depopulation was not formally declared as a policy in the area, but prolonged neglect resulted in deterioration of properties and constant reduction in the number of residents in the area. At some point in 2007, the Conservative government made an official policy not to re-rent houses that were vacated, even if they were in good shape. The MP for Ajax-Pickering, Mr. 
Holland, declared this to be an under-handed way of depopulating the land for the airport (Calis, 2007).

There are some positive aspects of organizing protests, namely social learning and bounding. Such aspects were emphasized by Thompson (1994) in his work as well. Residents of Stouffville who protested in 1974, vowed 25 years later to teach young residents every trick they knew, when the airport plans were reviewed in 1998. A positive development for the land happened recently regarding one-year agricultural leases. In 2017, Transport Canada announced it will start implementing 10-year leases, to go into effect in 2018 (Calis, 2017). The new policy became effective around the time when the agri-study ordered by LOL was completed. The study indicates that long-term tenancy security is a crucial factor for farming viability and profitability.

Here is a brief summary of what transpired during almost five decades. In the early stage of the FLP story development, the public was mainly excluded from the decision-making process. After citizens had organized to protest the decision to build an airport and expropriate the lands in Pickering, the federal government reluctantly responded to the pressure for more transparency and public engagement, which eventually led to the public hearings and inquires. The first of the two hearings (Swackhammer) represented true deliberations, defined as qualitative discussions intended to bring closer opposing stakeholders. The second inquiry (AIC) was less about the deliberations and more about bringing legitimacy and formalizing the process of building the airport, since the restrictions on bringing evidence and witnesses were imposed. After inquiries were finished, opposing sides remained entrenched in their positions. On the surface, it appeared that public consultations were not useful because the gap between airport planners and protesters remained, and planners continued to make plans and protesters to protest. However, public forums delayed the policy implementation, and educated the public, which helped in project shelving. Since then, there have been no other deliberations like the Swackammer hearings, so a conclusion that public forums do not have a purpose is based on one data point. If the government organized fair argument exchanges instead of years of planning, this story might have been closed. 


\section{Chapter 5 - Reasons for the delay}

The literature on Pickering highlights some of the findings from the researched documents and helps to put important events into a socio-historic context. After reviewing this literature I will outline the factors that contributed to the length of this case.

\subsection{The Literature on Pickering}

Earlier studies on the Pickering Airport story have been insightful in gaining detailed accounts of what happened over the years. Some of these studies were undertaken by activists opposing the airport (Massey and Godfrey, 1972; Budden and Ernst, 1973; Stewart 1979; Thompson 1994), while some were from academic research (Abouchar, 1978; Borins, 1979; Feldman and Milch, 1982; 1983; Rowan 2017; Rowan, 2019).

Massey and Godfrey (1972) provide a vivid account on how POP was formed and the effects of expropriations on peoples' lives on the first six months after the March decision. Their analysis of why the second airport was chosen to facilitate future air-travel demands, instead of expanding Malton, is instructive. The residents around Malton protested a possible noise increase from the airport expansion and the government interpreted this protest as a veto of any talk about Malton. According to authors, this was 'over kill', an extreme government reaction to the objections of the residents surrounding Malton, who were against a noise increase but were not against any development due to possible job opportunities.

One part of Movable Airports by Budden and Ernst (1973) is Ernst's account of the protests around Orangeville, which was coincidentally abandoned as an airport location before Pickering was chosen as the airport site. The other part of the book by Sandra Budden provides similar accounts of what happened with the airport planning in Pickering as given by Massey and Godfrey (1972). Budden and Ernst concluded that the government decisions were political, not results of good planning. They also complained that politicians were reluctant to invite the public into the planning process. Their most important conclusion of what has transpired during two processes around Orangeville and Pickering is that the majority of government officials were 
deceitful, and that politicians sowed mistrust in a great number of people who had faith in the government at that time.

Stewart (1979), who was a journalist, devoted parts of his book examining what happened at Mirabel to draw parallels with the mess the government created around Pickering. He also provided lots of details on POP activities, which span from producing technical reports to confronting government planners in their justifications for the airport, to working on gaining public support for protesters' cause, and finding ways to engage politicians in order to persuade them to reverse the plan for building an unnecessary airport.

The main outcome of Stewart's research is that the lack of transparency was the main culprit behind the turmoil. The lack of transparency was twofold: he concluded that the information available to citizens was limited, and that the inner workings of the federal bureaucracy were also secretive. His stipulation that self-serving bureaucrats were pushing politicians was disputed by Borins (1979), who claimed that politicians were just responding to various inside and outside pressures. Regardless who was the main driver of decisions in the Pickering case, Stewart has a valid point regarding the role of transparency in the unfolding of this story. Stewart found it crucial that a report showing how the Pickering site is not suitable for an airport because of airspace conflicts with the existing airport at Malton was not disclosed at important meetings. For some of the claims, he could not provide references because they were private, but most of his claims are backed up by Thompson's account of what happened, and some could be corroborated by available government documents.

In 1978, Alan Abouchar, from the Department of Political Economy, University of Toronto presented the paper Traffic Forecasts for the Pickering (Second Toronto International) Airport:A Critical Examination. At that time, the project was already stopped, but he found that traffic forecasting procedures employed for such a large investment were appalling, and needed to be re-examined if the project is ever revitalized.

Sanford F. Borins, while he was at the Graduate School of Management, Northwestern University, provided an interesting overview of the events leading up to the 1975 decision to stop the airport development in Self-regulation and the Canadian Air Transportation Administration: The Case of Pickering Airport, by analyzing CATA behavior. He did not see the numbers regarding the noise forecast that were used to justify the need for the Pickering Airport to be 'cooked', as POP people had been claiming. His interpretation is that less sinister reasons were 
behind it, and that noise extrapolations were based on available information at that time, without hindsight of what would happen with the airport noise reduction in the future. He finds that political risks assessment was behind opting for the new airport, instead of expanding Malton, and that choosing Pickering was considered an easy acquisition, involving expropriation from only a few hundred residents. He also claims that the main reason why Premier Davis decided to withdraw his support for the project after elections was to eliminate a point of agreement between new NDP and Liberal members of the minority government

In the period after the airport plan was shelved, Elliot J. Feldman and Jerome Milch conducted over a hundred interviews with politicians, government planners and protesters to write two accounts of airport planning in Canada at that time. In their 1983 book, The Politics of Canadian Airport Development, lessons for federalism, they offered political analysis of the problems of three airports, Pickering, Montreal and Vancouver, and focused on Canadian federalism. Their general conclusion regarding land-use policies around Mirabel and Pickering is that there were none, and there were no plans or policies regarding traffic distribution around the two-airport systems of Montreal and Toronto. On the account of transparency the authors confirm what one could learn from Movable Airports and Paper Juggernaut. Government officials were reluctant to provide critical data on decisions regarding airport developments. The secrecy during site selection was necessary to avoid land speculation and local-market distortions, while disclosing technical data to lay public was unnecessary. Both of these reasons were rejected by airport opponents, and the contempt of civil servants at that time toward public participation was two-fold. First, ordinary citizens did not have a legitimate right to participate in the decision making process, because this mandate was given to civil servants by elected governments. Second, citizens did not have the necessary training to partake in policy-making on equal terms, so they could only participate in consultations in which they would be informed about important decisions.

The authors' other account of this period was given in the 1982 book Technocracy versus Democracy; The Comparative Politics of International Airports, where more technical analysis of the three airports is performed and compared with five other international multi-airport designs at that time. The authors made important conclusions regarding the role of experts in decision-making processes. First, there was a power imbalance between the stakeholders who planned airport developments and the citizens' groups opposing new facilities, reflected in the 
access to information and the amount of resources at their disposal. In some cases, citizens could not afford to hire experts to confront government studies, which were obtained by engaging powerful consulting companies the authors call hired guns. Second, the authors identified how a bias from the political side towards the development of new facilities was transposed into forecasts that supported the desires of the politicians. Politicians and bureaucrats preferred optimistic prognoses for future passenger loads and pessimistic estimates of the 'hardware' on hand. This bias resulted in inflated air-traffic projections from experts on the government side, which provided more ammunition to the protests that initially started as the result of property expropriations.

Thompson and Rowan provided detailed accounts on the protests up until 1975, the deliberations between protesters and government representatives, the role of the media and POP engagement, and a lot of insight for this analysis. Thompson showed that a relatively small group of citizens can stop government mega-plans if they learn how to successfully utilize science and expertise to confront government experts. Both Thompson and Rowan analyzed how the media covered these events, and the relation between POP leaders and journalists. Rowan confirms Thompson's conclusion that the key to the success of stopping the airport was that protesters were smart and witty, and learned how to manage media in order to sway public opinion and pressure federal and provincial governments.

Regarding public participation, both question the effectiveness of public forums in determining land-use policy. Thompson concludes that the AIC process did not conform to true deliberations, since there were no consultations, and no dialogue. This was merely a public relations exercise by the federal government after a decision had been made. Similarly, Rowan finds that the political forces in Ontario and Ottawa and the policy questions around regional growth and urban sprawl contributed more to the defeat of the airport than the airing of public grievances. Their findings are that all sides in the argumentation, protesters and government bureaucrats, believed that the process of deliberation had little merit, and neither side was willing to concede its ground over the Pickering Airport.

On the reason why the plan was shelved they both come to similar conclusions, that the important factor in this story was the provision from the initial agreement between federal and provincial governments regarding who was going to provide the infrastructure. Thompson finds that the reason the airport was shelved in 1975 was due to the provincial government's refusal to 
finance and build such an infrastructure, when it became convinced that the airport was not needed. An interview with Premier Davis, in which he told Thompson that POP had a big impact on his decision, supports this conclusion. According to Rowan, the biggest factor was the change in the political constellation of the provincial government, because Premier Davis changed his stance on the project only after the provincial election in 1975.

\subsection{Indecision and lack of transparency}

One of the key reasons for the long delay was the government's indecision, partly triggered by public resistance, partly by changes in government priorities, and partly by differences in federal, provincial and local government interests.

The federal government organized public hearings, namely the Swackhammer hearings, to fulfil its legal obligations under the Expropriation Act (1970). Then, it set up a commission to inquire about the need for the Pickering Airport, the Airport Inquiry Commission (AIC) under Judge Gibson, following significant and effective protests led by POP. Because of confusing, and somehow contradictory recommendations by Gibson's commission, a cycle of new studies regarding the airport was initiated. The first one was the SOMTS, which was jointly undertaken by the federal and provincial governments, and was scheduled almost immediately after the decision to shelve the plan, at the end of 1975.

The requirement for the SOMTS study was to keep the option of an airport in Pickering and to protect that land from development until building the airport would be a necessity. It appeared that the government was not satisfied with this study that recommended expanding Malton, while delaying the Pickering Airport at least for a decade. Consequently, the federal minister asked for further studies (Daw, 1979).

The next action from the government was the South Ontario Area Airports Study (SOAAS), which was initiated in 1989 and released in 1995. Government experts and advisers continued to analyze this case from 1998, when Pickering was declared an airport site, and assembled zoning regulations that were made legally binding in 2001 and 2004 (Government of Canada, 2001; 2004). Those studies were not officially named, and the government appeared lost in the decision-making process, contemplating whether Toronto Island Airport or Buttonville, a private airport in Markham, would be closing in the near future. A draft plan from 2005 that proposed a two-runway GA airport was caught between the change of power in federal 
parliament between Liberals and Conservatives: in 2006 Conservative majority was formed under Prime Minister Stephen Harper.

Consequently, another study was announced in 2007, when TC gave a short-term contract to the GTAA to study the need for the Pickering Airport. The study was finished early in 2010, but it was released in July 2011. Public consultation and protests continued, and a Needs Assessment study was ordered in 2007, released to TC in 2010, and made public the next year. Based on that study, the Harper government declared again that Pickering would be an airport site in 2013, and started making plans to build an airport. The cycle of consultations and protests was repeated, and two more studies happened: Dr. Polonsky's and KPGM's. What was interesting in these studies was that they would take a long time to decide, which would result in further delays in the decision-making process. Looking at some of the key studies that affected the decision making process about the Pickering Airport, one can see their role in this long delay. Table 5.2 summarises the major studies ordered by the government from 1972 to the present, listing the approximate years that each study contributed to delaying airport construction.

Studies before the first airport announcement lasted roughly from 1967 to 1972. If this period is included, it amounts to roughly 25 years of formal studies, conducted on behalf of federal and sometimes provincial governments to justify the plan for an airport in Pickering. The math is not exact: some studies were finished a long time before their release, and some like SOMTS, were ordered by the end of year, so it were counted as a four-year study. The long delays and costly decision-making process was part of the reason for public distrust in the process. In addition, all studies were trying to determine when the Pickering Airport would be needed, but neither explored alternative options of utilizing the existing airport network in South Ontario.

Table 5.2 Studies performed to determine when the Pickering Airport would be needed.

\begin{tabular}{|l|c|l|c|}
\hline Years of study & Study Name & \multicolumn{1}{|c|}{ Conducted by } & Years lasted \\
\hline $1975-1979$ & SOMTS & Federal and provincial governments & 4 \\
\hline $1998-1995$ & SOAAS & Transport Canada & 7 \\
\hline $2007-2011$ & Needs Assessment Study & GTAA & $>4$ \\
\hline $2015-2016$ & Jets and Jobs & Dr. Polonsky & 1 \\
\hline $2016-?$ & Aviation Sector Analysis & KPGM & $>4$ \\
\hline
\end{tabular}


These long delays also affected the decisions of the local governments. Support from municipalities surrounding the FLP towards the airport had also varied across the region, and over time. The Township of Pickering was against the airport at the beginning, but at the turn of century the Town Council was considering not opposing the plan when the federal government announced in 1998 that it would protect the airport option with a new zoning regulation (Josey, 1994). Now, the Pickering mayor openly advocates for building the airport by publishing columns in the news (Ryan, 2019). Over time, some municipalities were against the airport, some were on board with the plan, and some were supportive with a string attached: if there was a need for the airport they would support it.

Why do the public consultations appear to be unsuccessful and dragging? An explanation needs to account for the fact that CBEOs in this case are participating in environmental land-use management by engaging government agencies associated with transport, ecology and agriculture. This management requires a lot of resources to find appropriate experts and manage contacts with officials at two levels of government. The Pickering case is a technical one, pertaining to the wider transportation needs of the public and industry. In addition, some ministers are supportive of the CBEO's efforts and some are not. This is a factor because usually ministers from different fields are not stepping over their colleagues in the same government, particularly if they are from the same party, which makes things for citizens more complicated. Also, it happened that different departments were not consulting one another at every turn. For example, one witness in the Swackhammer hearing from the Department of Agriculture stated he was not aware of the Pickering issue, and that his department was not consulted prior to the 1972 announcement. Whether the province was sidelined in 2013 re-announcement, or both governments played politics, is not that crucial, it is more important that ministers have not boosted public trust in the process.

On the technical side, Feldman and Milch's (1982) observation of the tendency of forecasters to produce estimates of passenger demand, aircraft movement, airport capacity, economic development, and noise consistent with the preferences of their clients reinforces the idea that the origin of experts' forecast errors is not entirely methodological. This puts additional pressure on CBEOs, to match the level of experts the government can employ. The main objection by POP and LOL to the majority of reports was that studies were based on the premise that the airport in Pickering is a given, something that will happen due to government promises. 
Because of this assumption, alternatives to Pickering were often ignored, or given less weight. LOL complained regarding Dr. Polonsky's work, which was based on interviews with a variety of stakeholders, that the majority of questions were formulated as if there was no alternative to the Pickering Airport.

Another big issue with government studies is the conflict of interest and independence. Many studies were done for TC by entities closely connected to TC, like GTAA, which is in the business of building and maintaining airports. Also, the whole notion that Dr. Polonsky's is the first independent analysis was contested, because questionnaires used in his interviews were provided by TC.

So it is fair to say that a constant in this story was that the federal government never truly explored alternatives to Pickering. At beginning, it ignored arguments that it would be better to expand Malton, because of the expected political pain from residents protesting a noise increase. Even later, when Pearson was expanded and studies were projecting passenger flow would eventually surpass its capacity; the experts employed by the government did not appeared to thoroughly consider the existing airport infrastructure in Southern Ontario. The first and only option recommended to the government was to build a new airport that served as fuel for CBEOs to continue the fight and as a catalyst to attract supporters. Again, this is along the lines discussed by Feldman and Milch (1982), but provides underlying reason for public consultations appear to have failed so far: it is hard to listen to an argument if the mindset is already predetermined towards desirable outcome.

Most importantly, the public hearings at the beginning were rarely two-way communications between government officials and citizens. Witnesses from both sides could provide their arguments, and media could report directly to the public. Most of the public interaction with government was through commenting periods, when the government was supposed to listen to the input from various stakeholders. The results of these interactions were seldom known, until the next announcement that the same policy of keeping the FLP for an airport would remain in place. As stated earlier, two-way interactions are a prerequisite of transparent governing.

The only true deliberations in recent times happened toward the end of 2018, when Susan Reesor and Jim Miller had a chance to present the LOL's research to the Standing Committee on 
Finance (2018) in Ottawa. It is too early to measure the impact of this single event, since then, the Liberal majority after the 2019 election in Ottawa is smaller but still runs the government.

As indicated in Sec. 4.1, there were several reasons why Pickering became the airport site, but lack of government transparency in announcing this decision was one of the main reasons for civic resistance in 1972. Frequent changes in government decisions would strengthen this impression among the public, such as in the case of expanding Malton (Ontario Government, 1972), and then switching to Pickering (Stewart, 1979).

The ordering of the KPGM study, while Dr. Polonsky's study was conducted, could be interpreted as a sign that politicians might be paying attention to what public demands and experts had to say. At the same time, it could be that 'more studies' is an easy solution for any government to avoid tough political decisions, because the inner workings of the process are still not fully transparent. Today, TC is explicit on their website devoted to Pickering lands that any future decision on the development of the lands will be made based on a sound business case and updated data on aviation demands and capacity, which are three prongs of the KPGM study.

However, one interpretation of the KPGM engagement would be a confirmation of the predictions from Feldman and Milch (1982), that the government employs aviation experts that would read the cues from the ordering agency. This company is as big a hired gun as it could be, world-leading consulting agency. The future will tell if they will explore alternatives to Pickering to the satisfaction of airport opponents.

\subsection{Citizens in action}

Before this area became the political 'battlefield' for the second major airport in Toronto, agriculture was the main business on the lands designed for the airport for a century and a half. The Miller family who were Scottish immigrants, began importing quality livestock from the United Kingdom in 1852, and built the Thistle Ha' Farm (HSMBC, 1973). Today, Jim Miller, a co-owner of the farm and head of research of LOL, is trying to convince the government to preserve the farmland of the FLP.

From a historic perspective, civic opposition to government action, or sometimes inaction, did not start with the POP protests in 1972. The first documented rebellion against British governance dates to 1837 , when settlers tried to resolve various grievances with the government regarding issues of religious freedom, taxation, and unfair land granting, among 
others (Sabean, 2000). The government was not open to listening to them, so some residents took up arms. However, the rebellion was quickly squashed, and most of the rebels ended up in jail, to be released later. Sabean (2000) concludes that the moral of this story is not an apparent immediate failure of the rebellions, but what happened later. The government opened its eyes and meaningful reforms followed, addressing issues that were the cause of the rebellion. This indicated that a strong civic opposition, even if not conducted in a civil way, could result in real changes for the population.

POP is the first CBEO in the Pickering area, and some of its activities were discussed earlier. There is a general consensus among scholars, politicians and journalists that POP's actions had substantial influence on stopping the Pickering Airport development in 1975. The most significant actions of this group are provided in a Toronto Star article (Casey, 2012). However, members of this group also participated in government activities, as representatives in the provincial parliament and as members of a committee appointed by the federal government.

LOL was the second successor of POP, after a relatively short tenure of the VOCAL group. Besides staging protests, LOL members actively engage in writing opinion articles in newspapers. From private conversation with the LOL's chair, their joint effort with GDA from 2009 to 2012 to produce a memorandum on how best to manage agricultural lands in Pickering (Green Durham Alliance, 2012) had a significant impact on the government's approach to the problem, and helped in reducing the amount of land reserved for the airport site. The agricultural study (Kubursi and Groenewegen, 2018) that LOL initiated in 2017 is also a significant achievement. The results of this study helped create a document that lists 12 powerful reasons why the federal government should abandon the plan for the airport in this location, and protect it from development in perpetuity as an agricultural hub. The report and this document were presented to federal ministers in Ottawa by the end of 2018.

The significance of the Kubursi and Groenewegen (2018) report is reflected in fact that now every CBEO can use it to counter the arguments of airport proponents with concrete data about the economic potential of the FLP. One of the main arguments for building an airport in Pickering is that it will serve as an economic engine for the whole Durham region. It was not lost on LOL members that the title of the report of independent advisor Dr. Polonsky (2016) is 'Jets and Jobs', indicating the inherent bias of the study. It is clear that the economic impact of an agricultural hub cannot compete with an airport, provided the airport attracts passengers. LOL 
member Jim Miller admitted that fact during discussions with the Standing Committee on Finance in October 2018. However, the counter argument is now on solid ground: jobs from agriculture and tourism can be generated with certainty now, not some 20 years later by an uncertain airport endeavour, while the likelihood of airport success depends on the level of government intervention on stirring passengers around the GTA.

North Pickering became an airport site as a consequence of urban sprawl, more precisely from one unsuccessful attempt to control it. In the late 1960s, at the time the federal government was preparing for the influx of an increasing number of passengers, the provincial government was looking to sustain urban development on the western side of Toronto, by promoting development in the north-east. The strategy was presented in the Toronto Centered Region (TCR) development plan by the Ontario Government (1970a). The policy of conforming to this idea of 'balanced' urban sprawl in Toronto became one of the main drivers behind the decision to designate Pickering as a place for a major airport, as already explained.

Anyway, the airport development would inevitably contribute to the urban sprawl, which usually follows a rapid increase in transportation (Brueckner, 2000; Nechyba and Walsh, 2004). Already at that time it was questionable if the urban development envisioned by the TCR concept would be balanced, which was pointed out by the Pickering Impact study, conducted on behalf of the city of Toronto by Diamond and Myers (1974). In addition, White (2016), in his book on Toronto urban planning, explained that developing Cedarwood before the airport would be counterproductive to TCR objectives, because it would create a disconnected urban development (i.e. more sprawl). It is interesting to note, that the TCR concept was dismantled without big a announcement (White, 2016), coincidentally at about the same time as the airport was shelved. 


\section{Chapter 6 - Conclusions}

With the hindsight of 45 years, it is not hard to find an answer to the question of whether the airport was needed. A lay person's analysis would have a clear conclusion: if the airport was really necessary, it would have been built by now. One would expect that private investors would find a way to push the business case to the government and sway the public and media towards the airport's construction. It is telling that this did not happen. However, by looking into the $25-$ plus years of government studies, it can be concluded that the airport was not needed: neither 45 years ago, nor 15 years ago. The evidence as to whether the Pickering Airport was necessary can be found in the GTAA studies from 2004 and 2010, and the Transport Canada land-use policy from 2017. The plan from 2004 asked for the airport in Pickering to be operational by 2012, and the report from 2010 predicted that the earliest time the airport will be needed is 2027. This means that constructions should have commenced, or should be starting soon, in the next few years at least. The need for an airport from these estimates does not correlate well with the Transport Canada decision to start accommodating 10-year leases to interested farmers. This decision most likely prevents the airport's construction before 2028, unless TC defaults on its obligations. The shift in land-use policy invalidates GTAA predictions up to 2027.

What are the most important factors that contributed to the long delay of the airport's construction? The short answer: it resulted from the interplay between government indecisiveness and civic activism. Governments' indecisiveness in the decision making process, triggered by federal and provincial jurisdictional boundaries, electoral concerns, frequent changes in policy and lack of transparency that would convince opponents all led to the delay. Civic activism, as well, was another important factor in this delay. Opponents' determination, persistence and mobilization by using media and scientific advice effectively played a crucial role in shaping the outcome.

Government documents were not accessible to the public before protests. The secrecy on the government side was partially to avoid land speculations, and partially because the government did not believe the technical information would be useful to citizens. However, after gaining access to these documents, POP's research section used that documentation to build a case that building the airport in Pickering was not a thought-out plan. By studying the government air-traffic forecast and conducting its own research, POP concluded that there was 
no need for an airport in the first place. Based on that, and its media skills, POP was able to paint a picture that was not favourable to government, and to gain public support for its cause.

The research conducted by CBEOs remains a powerful tool for less powerful players to engage in the planning process, and confront more powerful government experts and planners, who had to go to the drawing board several times during four decades since the shelving of the original plan. The public engagement in the technical studies has prolonged the project evidently, but so have government studies, for a quarter of the century. The expert advice through various commissions also contributed to the change in stewardship of half of the expropriated federal land that was transferred to the RNUP. Although this is not the result of LOL's direct involvement in the policy change, some seeds of the process were planted by POP members in the 1980 s.

The remaining question is: what was the role of public deliberations? First, public participation in land-use policy had a direct impact on protection of the land in question. The land is still arable. Was utilizing experts or organizing public forums key in this success? The Swackhammer hearings were a key first step in the postponement of the airport plan. Without these first hearings, the next public inquiry might not have happened. In any case, the AIC delayed the process for two years until the provincial elections, which proved to be pivotal to the outcome. If the Swackhammer hearings were structured differently and the voices of those excluded at that time were not heard, POP's protests would not be enough to stop the government from starting construction.

The lack of deliberation is evident in the years after 1975. Several studies that Transport Canada conducted over time were controversial or not clear, such as the statement that the airport will be needed some time in 2027 or 2041, and were not discussed in a true public forum where all stakeholders would get a chance to challenge findings from government planners. A genuine deliberation involving all stakeholders happened in 2018, when LOL had a chance to present its research to the Standing Committee on Finance, and federal ministers in Ottawa. It is too early to measure the impact of this single event, since the Liberal Party lost its majority in Parliament after the 2019 elections.

After years of urban development, important infrastructure, like Highway 407, is now in close proximity of the Pickering Airport location, so that the federal government's reliance on the province might have diminished. On top of that, the province and many local municipalities 
are now supportive of the airport's development, so the pressure is mainly on the federal government. It is a question of whether the issue of airport infrastructure could emerge as a point of contention between different jurisdictions that would stop the airport again.

What is more important: farmland or runaways? Citizens will answer this question by electing representatives who favour one option or the other. In the last two federal elections, citizens in the region predominantly voted for MPs who were against paving the lands without good reason.

With changes in the electoral make-up of the community one may also speculate that public priorities might change and there can is a possibility that politicians who prefer airport development might get elected in local and provincial elections.

As a final reflection, I would like to mention that my original plan was to conduct interviews with various key actors involved in this process since the 1970s. I would like to thank the many people who generously shared their files, time and knowledge with me. Unfortunately, health problems and time shortage limited this project to a literature and archival review. Previous researchers draw on interviews with stakeholders who participated in the first chapter of this story that was closed 45 years ago. However, this story is still developing. For future research, it would be interesting to explore how non-transportation related environmental and societal priorities, such as food security or climate change, may affect the decision-making process regarding government action. It would also be important to look at the relationship between the FLP story and the environmental battles that helped protect the Oak Ridges Moraine and Rouge National Urban Park, which both have parcels of lands that were part of the original Federal Lands in Pickering stock. 


\section{References}

Abbruzzese, T. V., \& Wekerle, G. R. (2011). Gendered Spaces of Activism in Exurbia: Politicizing an Ethic of Care from the Household to the Region. Frontiers: A Journal of Women

Studies, 32(2), 140. doi: 10.5250/fronjwomestud.32.2.0140

Abouchar, A. (197). Traffic Forecasts for the Pickering (Second Toronto International) Airport: A Critical Examination. Canadian Public Policy / Analyse De Politiques, 3(1), 14. doi: $10.2307 / 3549595$

Adkin, L. E., Hanson, L. L., Kahane, D., Parkins, J. R., \& Patten, S. (2017). Can public engagement democratize environmental policymaking in a resource-dependent state? Comparative case studies from Alberta, Canada. Environmental Politics, 26(2), 301-321. doi:10.1080/09644016.2016.1244967

Airport plan shelved in 1975 Pickering land disposal considered. (1985). Globe and Mail, Toronto, ON, May 17, 1985, p. M1.

Airways. (2014, January 29). Toronto Pearson International Airport, Then and Now: Part Two. Airways Magazine. Retrieved from airwaysmag.com/uncategorized/toronto-pearsonairport-history

Angry Pickering residents pushing govt. to keep expropriated land and create park: [FINAL edition] (1987). The Ottawa Citizen, Aug 14, 1987. pp. A4

Armitage, D., Loë, R. D., \& Plummer, R. (2012). Environmental governance and its implications for conservation practice. Conservation Letters, 5(4), 245-255. doi: 10.1111/j.1755263x.2012.00238.x

Armstrong, J. (1998). Federal government viewed as Pickering's 'slum landlord'. Globe and Mail, Toronto, ON, Apr. 6, 1998, pp. A8.

Arnold, S. (1994). Airport study could hurt boom at Mount Hope manager warns. The Spectator; Hamilton, Ont., Oct. 14, 1994, pp. D1.

Atkinson, S. (2019). Farmland forum told Ontario can't feed itself. Ontario Farmer; London, Ont., Jun. 4, 2019, pp. A4.

Balance is needed for Pickering airport lands. (2012). Oshawa This Week, Mar. 9, 2012, pp. 1.

Ball, N. R. (1991). Building Canada: a history of public works. Toronto: University of Toronto Press.

Barlow, C. (2015). Documents as 'risky' sources of data: a reflection on social and emotional positioning - a research note. International Journal of Social Research Methodology, 19(3), 377-384. doi: 10.1080/13645579.2015.1051797

Bengston, D. N., Fletcher, J. O., \& Nelson, K. C. (2004). Public policies for managing urban growth and protecting open space: policy instruments and lessons learned in the United States. Landscape and Urban Planning, 69(2-3), 271-286. doi: 10.1016/j.landurbplan.2003.08.007 
Blizzard, C. (2013). Province 'blindsided' by airport plan? Who are they trying to kid? Toronto Star, Toronto Ont., 16 June 2013, pp. 7.

Borins, S. F. (1982). The toronto airport(s): Case A: The sequel to case A and the whole of case B Institute of Public Administration of Canada.

Borins, S. F. (1979). Self-regulation and the canadian air transportation administration: The case of pickering airport. Logistics and Transportation Review, 15(1), 131. Retrieved from http://ezproxy.lib.ryerson.ca/login?url=https://search-proquestcom.ezproxy.lib.ryerson.ca/docview/197433756?accountid=13631

Brueckner, J. K. (2000). Urban Sprawl: Diagnosis and Remedies. International Regional Science Review, 23(2), 160-171. doi: 10.1177/016001700761012710

Bruegmann, R. (2005). Sprawl: a compact history. Chicago: University of Chicago Press.

Budden, S., \& Ernst, J. A. (1973). The movable airport; the politics of government planning Sandra Budden Joseph Ernst. Toronto: Hakkert.

Byers, J. (1984). MP urges Ottawa to sell Pickering lands. Toronto Star, Nov. 7, 1984, pp. A7.

Calis, K. (2007). Homes not for re-rental. The News Advertiser, Ajax, Ont., Nov. 29, 2007, pp. A7.

Calis, K. (2017). Transport Canada extends farming leases on Pickering lands designated for a potential airport. Pickering News Advertiser, May 25, 2017. pp. 1.

Casey, L. (2012). How humour helped defeat an airport. Toronto Star; Toronto, Ont., pp. GT5.

Creighton, J. L. 2005. The Public Participation Handbook: Making Better Decisions through Citizen Involvement. San Francisco: Jossey-Bass.

Culver, K., \& Howe, P. (2004). Calling all citizens: The challenges of public consultation. Canadian Public Administration/Administration Publique Du Canada, 47(1), 52-75. doi: 10.1111/j.17547121.2004.tb01970.x

Das, R., Jain, K. K., \& Mishra, S. K. (2018). Archival research: a neglected method in organization studies. Benchmarking: An International Journal, 25(1), 138-155. doi: 10.1108/bij-08-20160123

Daw, J. (1979). Second airport not in plans Lang claims. Toronto Star, Nov. 6, 1979, pp. B8.

Dear, M. (1992). Understanding and Overcoming the NIMBY Syndrome. Journal of the American Planning Association, 58(3), 288-300. doi: 10.1080/01944369208975808

Delaney, M. (2018). Let's Put the Pickering Airport Issue to Rest Once and for All. Pickering News Advertiser; Ajax, Oct. 9, 2018.Retrieved from www.durhamregion.com/opinion-story/8953362let-s-put-the-pickering-airport-issue-to-rest-once-and-for-all.

Department of Transport, Canada (1979). Southern Ontario Multimodal Passenger Studies. Supply and Services, Canada.

Diamond and Myers (1974). Pickering impact study: A study prepared for the City of Toronto Planning Board of the impact of the proposed new Toronto international airport and the North 
Pickering community, by Diamond and Myers, Architects and Planners, Jack B. Ellis and Associates, Ltd. and Institute of Environmental Research Inc., Toronto.

Du, S., Shi, P., \& Rompaey, A. V. (2014). The Relationship between Urban Sprawl and Farmland Displacement in the Pearl River Delta, China. Land, 3(1), 34-51. doi: 10.3390/land3010034

Dupras, J., Marull, J., Parcerisas, L., Coll, F., Gonzalez, A., Girard, M., \& Tello, E. (2016). The impacts of urban sprawl on ecological connectivity in the Montreal Metropolitan Region. Environmental Science \& Policy, 58, 61-73. doi: 10.1016/j.envsci.2016.01.005

Elliot, J. (2014). Montreal's abandoned Mirabel Airport too costly to repurpose. CTVNews, August 20, 2014. Retrieved from https://www.ctvnews.ca/canada/montreal-s-abandoned-mirabel-airporttoo- costly-to-repurpose-1.1967712.

Ewing, R., \& Hamidi, S. (2015). Compactness versus Sprawl. Journal of Planning Literature, 30(4), 413-432. doi: 10.1177/0885412215595439

Feldman, E. J., \& Milch, J. (1982). Technocracy versus democracy: the comparative politics of international airports. Boston: Auburn House.

Feldman, E. J., \& Milch, J. (1983). The politics of Canadian airport development: lessons for federalism. Durham (N.C.): Duke University Press.

Frenkel, A., \& Ashkenazi, M. (2008). Measuring Urban Sprawl: How Can We Deal with It? Environment and Planning B: Planning and Design, 35(1), 56-79. doi: 10.1068/b32155

Fung, A. (2006). Varieties of Participation in Complex Governance. Public Administration Review, 66(s1), 66-75. doi: 10.1111/j.1540-6210.2006.00667.x

Fung, A. (2015). Putting the Public Back into Governance: The Challenges of Citizen Participation and Its Future. Public Administration Review, 75(4), 513-522. doi: 10.1111/puar.12361

Gilbert, L., Sandberg, L. A., \& Wekerle, G. R. (2009). Building bioregional citizenship: the case of the Oak Ridges Moraine, Ontario, Canada. Local Environment, 14(5), 387-401. doi: $10.1080 / 13549830902903674$

Gordon, P., \& Richardson, H. W. (1997). Are Compact Cities a Desirable Planning Goal? Journal of the American Planning Association, 63(1), 95-106. doi: 10.1080/01944369708975727

Government of Canada (1974). Report of J.W. Swackhamer. Ottawa: Information Canada.

Government of Canada (2001). Order Declaring the Pickering Lands as an Airport Site (SOR/2001297. Department of Justice. Retrieved from https://laws-lois.justice.gc.ca/eng/regulations/SOR2001-297/index.html.

Government of Canada (2004). Pickering Airport Site Zoning Regulations (SOR/2004-212). Department of Justice. Retrieved from https://laws-lois.justice.gc.ca/eng/Regulations/SOR-2004212/index.html.

Greater Toronto Airports Authority (GTAA) (2004). Pickering Airport Draft Plan Report. Transport Canada, Nov. 2004. 
Greater Toronto Airports Authority (GTAA) (2010). The Needs Assessment Study: Pickering Lands, Final Report. Transport Canada, March 2010. Retrieved from https:/www.tc.gc.ca/eng/ontario/pickeringstudy.htm.

Green Durham Alliance (2012). A Prospectus for Management of Federal Lands at Pickering. Green Door Alliance Durham Conservation. Retrieved from http://www.greendurham.ca/publications.

Gupta, A. (2010). Transparency in Global Environmental Governance: A Coming of Age? Global Environmental Politics, 10(3), 1-9. doi: 10.1162/glep_e_00011

Hakala, A. (1977). Second airport not in plans Lang claims. Toronto Star, Oct. 11, 1977, pp. B1.

Hanna, P., \& Vanclay, F. (2013). Human rights, Indigenous peoples and the concept of Free, Prior and Informed Consent. Impact Assessment and Project Appraisal, 31(2), 146-157. doi: $10.1080 / 14615517.2013 .780373$

Hanna, P., Vanclay, F., Langdon, E. J., \& Arts, J. (2016). Conceptualizing social protest and the significance of protest actions to large projects. The Extractive Industries and Society, 3(1), 217 239. doi: 10.1016/j.exis.2015.10.006

Hawkins, C. V., \& Wang, X. (2012). Sustainable Development Governance. Public Works Management \& Policy, 17(1), 7-29. doi: 10.1177/1087724x11429045

Hill, M. R. (1993). Archival strategies and techniques. Newbury Park, CA: Sage Publications.

Historic Sites and Monuments Board of Canada (HSMBC) (1973). Research report number: 1973D June, 2004-SDC/CDE-016. Parks Canada. Retrieved from https://www.historicplaces.ca/en/rep-reg/place-lieu.aspx?id=9632.

Hofmann, N. (2001). Urban consumption of agricultural land. Ottawa: Statistics Canada, Agriculture Division.

Intergovernmental Panel on Climate Change (IPCC) (2018). Global Warming of 1.5degC: Summary for Policy Makers. Intergovernmental Panel on Climate Change; Incheon, Republic of Korea, October 2018. Retrieved from http://report.ipcc.ch/sr15/index.html.

Irvin, R. A., \& Stansbury, J. (2004). Citizen Participation in Decision Making: Is It Worth the Effort? Public Administration Review, 64(1), 55-65. doi: 10.1111/j.1540-6210.2004.00346.x

Jami, A. A., \& Walsh, P. R. (2014). The role of public participation in identifying stakeholder synergies in wind power project development: The case study of Ontario, Canada. Renewable Energy, 68, 194-202. doi: 10.1016/j.renene.2014.02.004

Johnson, M. P. (2001). Environmental Impacts of Urban Sprawl: A Survey of the Literature and Proposed Research Agenda. Environment and Planning A: Economy and Space, 33(4), 717-735. doi: $10.1068 / \mathrm{a} 3327$

Johnson, P. (1987). Residents vow to fight 'to the hilt' over sale of Pickering airport lands. Globe and Mail, Toronto, ON, Aug. 15, 1987, pp. A9.

Josey, S. (1998). Pickering residents revive 25-year-old airport battle. Toronto Star; Toronto, Ont., Aug. 9 1998, pp. 1. 
Josey, S. (2002). Pickering airport idea taking off again, Ottawa resurrecting plan killed by protest after expropriation. Toronto Star; Toronto, Ont., Feb. 11 2002, pp. 3.

Khagram, S., Fung, A., \& Renzio, P. D. (2013). Open budgets: the political economy of transparency, participation, and accountability. Washington, D.C.: Brookings Institution Press.

Kinzer, K. (2018). Picking up speed: public participation and local sustainability plan implementation. Journal of Environmental Planning and Management, 61(9), 1594-1611. doi: 10.1080/09640568.2017.1358154

Krauss, C. (2004). End of Era Near in Montreal for White-Elephant Airport. The New York Times, Oct, 3, 2004, pp. N18.

Krick, E. (2019). Creating participatory expert bodies. How the targeted selection of policy advisers can bridge the epistemic-democratic divide. European Politics and Society, 20(1), 101-116. doi: $10.1080 / 23745118.2018 .1515865$

Kubursi, A. and Groenewegen, J. (2018). A Future for the Lands: Economic Impact of Remaining Pickering Federal Lands if Returned to Permanent Agriculture. Econometric Research Ltd and JRG Consulting Group. Retrieved from https://landoverlandings.com/wpcontent/uploads/2018/04/Final-Report-Mar-7-FINAL.pdf.

Lang, G. (2018). Urban energy futures: a comparative analysis. European Journal of Futures Research, 6(1). doi: 10.1186/s40309-018-0146-8

Laurian, L., \& Shaw, M. M. (2008). Evaluation of Public Participation. Journal of Planning Education and Research, 28(3), 293-309. doi: 10.1177/0739456x08326532

Lee, C., Won, J. W., Jang, W., Jung, W., Han, S. H., \& Kwak, Y. H. (2017). Social conflict management framework for project viability: Case studies from Korean megaprojects. International Journal of Project Management, 35(8), 1683-1696. doi: 10.1016/j.ijproman.2017.07.011

LOL (2017). Build It but They Won't Come (Unless forced to). Land over Landings. Retrieved from https://landoverlandings.com/resources/research-report-8-build-it-but-they-wont-come-unlessforced-to.

LOL (2016). Timeline. Land over Landings. Retrieved from https://landoverlandings.com/beinformed/timeline.

LOL (2018). Food is growing concern. Land over Landings. Retrieved from https://landoverlandings.com.

Lu, V. (2013). New Pickering airport plans leave farmers in limbo: Project's revival dims hopes for those who remain on land after decades of uncertainty. Toronto Star, Toronto Ont., 10 Oct. 2013, pp. B3.

Macaraig, J. M. R. (2015). Citizen Science and Greenspace Planning in the Rouge River Watershed. Journal of Environmental Policy \& Planning, 17(4), 435-451. doi: 10.1080/1523908x.2014.965808 
Malena, C. 2009. "Building Political Will for Participatory Governance: An Introduction.” In From political won't to political will: building support for participatory governance, edited by C Malena, 3-30. Sterling, VA: Kumarian Press

Massey, H. J., \& Godfrey, C. M. (1972). People or planes. Toronto: Copp Clark Pub. Co.

Mcgranahan, G., Schensul, D., \& Singh, G. (2016). Inclusive urbanization: Can the 2030 Agenda be delivered without it? Environment and Urbanization, 28(1), 13-34. doi:

$10.1177 / 0956247815627522$

McCulloch, G. (2004). Documentary Research: In Education, History and the Social Sciences. London: RoutledgeFalmer

McGrath, T. M. (1992). History of Canadian airports. Toronto: Lugus Publications.

McNair, B. (2019). Seaton community begins to take shape in north Pickering. The News Advertiser, Ajax, Ont., Oct. 3, 2019. pp.1

Milley, D. (2004). Pickering airport planning continues; while VOCAL contends need is decades away. The News Advertiser, Ajax, Ont., Apr. 30, 2004. pp.3

Milley, D. (2005). Resident arrested trying to halt demolitions. The News Advertiser, Ajax, Ont., Mar. 16, 2005. pp.1

National park on Markham's eastern edge keeps growing. (2015). Markham Economist \& Sun, 16 July, 2015, pp. 1.

Nechyba, T. J., \& Walsh, R. P. (2004). Urban Sprawl. Journal of Economic Perspectives, 18(4), 177-200. doi: 10.1257/0895330042632681

Neuman, M. (2005). The Compact City Fallacy. Journal of Planning Education and Research, 25(1), 11-26. doi: 10.1177/0739456x04270466

Neufville, R. D. (1995). Management of multi-airport systems. Journal of Air Transport Management, 2(2), 99-110. doi: 10.1016/0969-6997(95)00035-6

Newig, J., Challies, E., Jager, N. W., Kochskaemper, E., \& Adzersen, A. (2018). The Environmental Performance of Participatory and Collaborative Governance: A Framework of Causal Mechanisms. Policy Studies Journal, 46(2), 269-297. doi: 10.1111/psj.12209

Nuesiri, Emmanuel. (2016). Accountability of powerful actors for social and environmental outcomes. IUCN Natural Resources Governance Framework (NRGF) Conceptual Paper. doi: 10.13140/RG.2.2.15254.96329.

Ontario Government (1970a). Design for Development: The Toronto-Centred Region. Department of Treasury and Economics, Regional Development Branch, Ontario.

Ontario Government (1970b). Regional Impact of a New International Airport for Toronto. Regional Development Branch, Department of Treasury and Economics, Ontario, March 1970.

Ontario Government (1972). The Ontario Government and The Pickering Airport Site. Ministry of Treasury, Economics and Intergovernmental Affairs, Ontario, June 1972. 
Ontario, Legislative Assembly (1977). Official Report of Debates (Hansard). $31^{\text {st }}$ Parl., $1^{\text {st }}$ Sess., (July 5, 1977).

Ontario Ministry of Municipal Housing (2002). Ontario Smart Growth, Feb 11, 2002. Retrieved from http://www.ontla.on.ca/library/repository/mon/3000/10301678.pdf

Palma-Oliveira, J. M., Trump, B. D., Wood, M. D., \& Linkov, I. (2018). Community-Driven Hypothesis Testing: A Solution for the Tragedy of the Anticommons. Risk Analysis, 38(3), 620634. doi: $10.1111 /$ risa. 12860

Parker, M., Acland, A., Armstrong, H. J., Bellingham, J. R., Bland, J., Bodmer, H. C., ... Sutherland, W. J. (2014). Identifying the Science and Technology Dimensions of Emerging Public Policy Issues through Horizon Scanning. PLoS ONE, 9(5). doi:

10.1371/journal.pone.0096480

Pickering airport announcement blindsides province and locals. (2013). Mississauga News., 11 June 2013. pp.1

Pickering, T., \& Minnery, J. (2012). Scale and Public Participation: Issues in Metropolitan Regional Planning. Planning Practice and Research, 27(2), 249-262. doi: 10.1080/02697459.2012.661670

Pierce, T. and Ward, E. (2013). Canada Land Inventory. In the Canadian Encyclopedia. Retrieved from https://www.thecanadianencyclopedia.ca/en/article/canada-land-inventory.

Polonsky, G. D. (2016). Jets and Jobs: Summary of Findings from the Targeted Stakeholder Consultations by the Independent Advisor on the Economic Development of the Pickering Lands. Transport Canada. Retrieved from https://www.tc.gc.ca/eng/ontario/economic- developmentpickering-lands.html.

Porta, D. D. (2008). Eventful Protest, Global Conflicts. Distinction: Journal of Social Theory, 9(2), 27-56. doi: 10.1080/1600910x.2008.9672963

Protestors hope to ground airport plan (2005). Daily Commercial News and Construction Record, 78(222):2. Toronto, Ont., Nov. 17, 2005.

Reed, M. S. (2008). Stakeholder participation for environmental management: A literature review. Biological Conservation, 141(10), 2417-2431. doi: 10.1016/j.biocon.2008.07.014

Richardson, H. and Gordon, P. (2004). US Population and Employment Trends and Sprawl Issues. in "Urban Sprawl in Western Europe and the United States", ed. H. Richardson and C. Bae, Ashgate Pub. Limited.

Responsible, balanced approach for the future of the Pickering Lands ends decades of uncertainty: Lands are being committed for an airport, economic development and a national urban park (2013). Canada NewsWire; Ottawa June 11, 2013.

Rowan, M. (2017). “On Their Knees”: Politics, Protest, and the Cancellation of the Pickering Airport, 1972-1975. Articles Urban History Review, 45(2), 46-55. doi: 10.7202/1051385ar

Rowan (2019). Crash Landing: Citizens, The State and Protest Against Federal Airport Development, 1968- 1976. Doctoral Thesis, McMaster University. 
Rucht, D., Koopmans, R., \& Neidhardt, F. (1999). Acts of dissent new developments in the study of protest. Lanham, MD: Rowman \& Littlefield.

Ryan, D. (2019). What kind of city do Pickering residents want? Pickering News Advertiser, Opinions: Mayor Dave Ryan, 25 April 2019.

Sabean, J. W. (2000). Time present and time past: a pictorial history of Pickering. Pickering, Ont.: Altona Editions.

Salvati, L., Karamesouti, M., \& Kosmas, K. (2014). Soil degradation in environmentally sensitive areas driven by urbanization: an example from Southeast Europe. Soil Use and Management, 30(3), 382-393. doi: 10.1111/sum.12133

Savan, B., Gore, C., \& Morgan, A. J. (2004). Shifts in Environmental Governance in Canada: How are Citizen Environment Groups to Respond? Environment and Planning C: Government and Policy, 22(4), 605-619. doi: 10.1068/c12r

Slemp, C., Davenport, M. A., Seekamp, E., Brehm, J. M., Schoonover, J. E., \& Williard, K. W. (2012). "Growing too fast:" Local stakeholders speak out about growth and its consequences for community well-being in the urban-rural interface. Landscape and Urban Planning, 106(2), 139-148. doi: 10.1016/j.landurbplan.2012.02.017

Statistics Canada (2018). The socioeconomic portrait of Canada's evolving farm population, 2016. The Daily, Released: 2018-11-2. Retrieved from https://www150.statcan.gc.ca/n1/dailyquotidien/181127/dq181127b-eng.htm.

Standing Committee on Transport and Communications (2011). Proceedings of the Standing Senate Committee on Transport and Communications. Canada Parliament, Ottawa, Par. 41 ${ }^{\text {st }}$, Ses. 1, Iss. 3, Nov. 15, 2011. Retrieved from https://sencanada.ca/en/Content/SEN/Committee/411 /TRCM/03evc-49175-e.

Standing Committee on Finance (2018). Pre-budget Consultations in Advance of 2019 Budget. House of Commons, Parliament, Canada, Par. 42th, Ses.,1 Meet. 173, Ev., Oct. 4, 2018. Retrieved from https://www.ourcommons.ca/DocumentViewer/en/42-1/FINA/meeting173/evidence.

Stewart, W. (1979). Paper juggernaut: big government gone mad. Toronto: McClelland and Stewart.

Tang, S.-Y., Tang, C.-P., \& Lo, C. W.-H. (2005). Public Participation and Environmental Impact Assessment in Mainland China and Taiwan: Political Foundations of Environmental Management. Journal of Development Studies, 41(1), 1-32. doi: $10.1080 / 00220380420000276554$

Taylor, S. J., Bogdan, R., \& DeVault, M. L. (2016). Introduction to qualitative research methods a guidebook and resource. Hoboken, NJ: Wiley.

Teo, M. M., \& Loosemore, M. (2017). Understanding community protest from a project management perspective: A relationship-based approach. International Journal of Project Management, 35(8), 1444-1458. doi: 10.1016/j.ijproman.2017.08.004 
Terando, A. J., Costanza, J., Belyea, C., Dunn, R. R., Mckerrow, A., \& Collazo, J. A. (2014). The Southern Megalopolis: Using the Past to Predict the Future of Urban Sprawl in the Southeast U.S. PLoS ONE, 9(7). doi: 10.1371/journal.pone.0102261

Thompson, V. A. (1994). Workings of a Protest/Pressure Group in Attempting to Thwart a Major Project of a Senior Level of Government. Master Thesis, York University.

Toronto Food Policy Council (2001). Toronto Food Charter. City of Toronto. Retrieved from http://tfpc.to/to-food-policy-archive/toronto-food-charter.

Toronto Urban Growers (2019). Why grow food in the city? Toronto Urban Growers. Retrieved from http://torontourbangrowers.org/why-grow-food-in-the-city.

Transport Action Ontario (2014). Response to: Transport Canada Needs Assessment Study Pickering Lands, 2010. Transport Action Ontario, Nov. 2014. Retrieved from http://transportaction-ontario.com/wordpress/wp-content/uploads/2014/02/TAO-Pickering-Airport-NeedsAssessment-2014-02.pdf.

Transport Canada (1974). Airport inquiry commission report. Ottawa: Government of Canada.

Transport Canada (2011). Pickering Lands History. Government of Canada; Transport Canada; Regions; Ontario. Retrieved from https://www.tc.gc.ca/eng/ontario/pickering-history-1295.htm.

Transport Canada (2015). Pickering Airport Site Order. Canada Gazette, Part I, 149 (29). July 18, 2015.

Transport Canada (2017). Pickering Lands Fact Sheet. Government of Canada; Transport Canada; Regions; Ontario. Retrieved from https:/www.tc.gc.ca/eng/ontario/pickering-2030.html.

Tsebelis, G. (1995). Decision Making in Political Systems: Veto Players in Presidentialism, Parliamentarism, Multicameralism and Multipartyism. British Journal of Political Science, 25(3), 289-325. doi: 10.1017/s0007123400007225

UN Framework Convention on Climate Change (2015). Paris agreement. Dec. 12; UNTC CH: XXVII-7-d.

Use Pickering airport land for dump, committee urges. (1988). Toronto Star, May. 11, 1988, pp. A7.

Vallance, S. (2013). Living on the Edge: Lessons from the Peri-urban Village. International Journal of Urban and Regional Research, 38(6), 1954-1969. doi: 10.1111/1468-2427.12036

Vanclay, F., Esteves, A. M., Aucamp, I., and Franks, D. (2015). Social Impact Assessment: Guidance for assessing and managing the social impacts of projects. Fargo ND: International Association for Impact Assessment.

Vaughan, H. (2007). Citizen science as a catalyst in bridging the gap between science and decisionmakers. Citizen Science Toolkit conference, Cornell Lab of Ornithology. June 20-23.

Veeman, T. and Veeman, M. (2018). Agriculture and Food. In the Canadian Encyclopedia. Retrieved from https:/www.thecanadianencyclopedia.ca/en/article/agriculture-and-food.

Warner, S. L. (1981). Balanced Information: The Pickering Airport Experiment. The Review of Economics and Statistics, 63(2), 256. doi: 10.2307/1924096 
Weeks, E. C. (2000). The Practice of Deliberative Democracy: Results from Four Large-Scale Trials. Public Administration Review, 60(4), 360-372. doi: 10.1111/0033-3352.00098

White, R. (2016). Planning Toronto: the planners, the plans, their legacies, 1940-80. Vancouver: UBC Press.

Whitelaw, G., Vaughan, H., Craig, B., \& Atkinson, D. (2003). Establishing the canadian community monitoring network. Environmental Monitoring and Assessment, 88(1), 409-418. doi:10.1023/A:1025545813057

Winsor, H. (1972). Pickering airport to back Malton in regional plan. The Globe and Mail (1936Current), Mar. 18, pp. 1.

Xi, F., He, H. S., Clarke, K. C., Hu, Y., Wu, X., Liu, M., Shi, T., Shi, T., Geng, Y., and Gao, C. (2012). The potential impacts of sprawl on farmland in Northeast China - Evaluating a new strategy for rural development. Landscape and Urban Planning, 104(1), 34-46. doi: 10.1016/j.landurbplan.2011.09.003 